\title{
Ataques Especulativos sobre Dívidas e Dolarização*
}

\author{
Aloisio P. Araujo** \\ Márcia S. Leon***
}

Sumário: 1. Introdução; 2. Modelo Cole-Kehoe com moeda local; 3. Exercício numérico; 4. Conclusão.

Palavras-chave: crise da dívida; manchas solares; dolarização; ataques especulativos.

Códigos JEL: F33; F34; F36; F47 e H63.

Este artigo faz uma extensão do modelo de crise da dívida de Cole e Kehoe (1996), com a adição de moeda local à versão original. No modelo modificado, o governo dispõe de uma alternativa aos títulos públicos indexados ou denominados em moeda internacional, que são os títulos denominados em moeda local. Em alguns casos, a opção da dívida pública em moeda local dá ao governo um recurso adicional para evitar crises do setor externo. Contudo, a introdução de moeda local permite o aparecimento de um banco central sujeito a pressões políticas do governo e que recorre à inflação da moeda local, mesmo na ausência de ataque especulativo sobre a dívida externa. Com estes dois modelos para uma economia com moeda local e um banco central que pode estar sujeito a pressões políticas, comparam-se os níveis de bem-estar do governo no modelo Cole-Kehoe, que reproduz uma economia dolarizada. São realizadas simulações para a economia brasileira no período de junho de 1999 a maio de 2001. Entretanto, estes exercícios numéricos utilizam hipóteses fortes para superar a questão da dimensionalidade.

This paper expands the Cole and Kehoe (1996) model of debt crisis, by bringing in local currency. In the modified version, the government holds, not only debt instruments denominated in foreign currency, but also carries debt instruments in local currency. Under some circumstances, the partial default on the debt denominated in local currency makes way for the establishment of a central bank that is subject to political pressures from its government and that decides to devalue the local currency even though there is no speculative attack on the external debt. By using this model for an economy with local currency and a central bank that may be under political pressure, it is possible to compare the welfare levels between this economy and the one from original Cole-Kehoe models, which portrays a dollarized economy. Simulations are done for the Brazilian economy for June

\footnotetext{
* Artigo recebido em nov. 2000 e aprovado em set. 2001. A visão apresentada no texto reflete o ponto de vista dos autores e não do Banco Central do Brasil ou de seus membros. Os autores agradecem aos professores Renato Fragelli, Ricardo Cavalcanti e Arilton Teixeira e dois pareceristas anônimos os comentários sobre este artigo. Os erros remanescentes são responsabilidade dos autores.

** Professor do Impa/RJ e da EPGE/FGV.

*** Aluna de doutorado da EPGE/FGV e funcionária do Banco Central do Brasil.
} 
1999 until May 2001. However, we should be careful when interpreting the results, since the numerical exercises suppose strong hypothesis to overcome the dimensionality problem.

\section{Introdução}

Este artigo trabalha com o modelo de crise da dívida de Cole e Kehoe (1996, 1998 e 2000) e incorpora a moeda local à versão original. A presença de duas moedas permite dois tipos de dívidas (uma em moeda local e outra em dólar) e, desta forma, abre a possibilidade de evitar crises do setor externo.

No modelo original, existe apenas uma moeda e considera-se que a dívida pública seja denominada ou indexada ao dólar e de propriedade dos banqueiros internacionais. Sua aplicação ao México admite a inclusão dos tesobonos na dívida pública denominada em dólar, $2 / 3$ dos quais pertenciam aos credores externos no período anterior à crise de 1994/95.

Com a emissão de uma parcela da dívida pública em moeda local, o governo pode recorrer à moratória parcial desta dívida e evitar uma crise externa. Este default parcial da dívida é atribuído à criação de um imposto inflacionário, apesar de moeda não ser explicitamente especificada no modelo. Em algumas situações pode ser preferível, em termos de bem-estar dos residentes, utilizar esta alternativa, do que suspender os pagamentos da dívida em dólar junto aos credores externos. Por um lado, uma moratória sobre a dívida em dólar produz efeitos contracionistas sobre a atividade econômica e também afasta o país do acesso ao mercado de crédito internacional por um longo período. Por outro lado, a moratória parcial da dívida em moeda local não causa danos desta mesma gravidade. A produtividade da economia não se reduz, porque os credores domésticos sabem que esta moratória é temporária e objetiva apenas obter recursos extras rapidamente para evitar um mal maior que é a moratória da dívida externa. A suspensão dos pagamentos da dívida em moeda local provocaria queda de produtividade da economia, se fossem totais, e não, parciais, como é o caso deste artigo.

Contudo, a introdução de moeda local possibilita o aparecimento de pressões políticas do governo sobre o banco central, com o intuito de aumentar os gastos públicos, mesmo na ausência de ataque especulativo sobre a dívida externa. 
As economias dolarizadas não dispõem de dívida em moeda local e, portanto, não contam com a alternativa do abatimento do valor real da dívida em moeda local para enfrentar uma crise da dívida em dólar. Sustentando-se neste argumento, Sims (1999) é contra a dolarização e apóia a inflação-surpresa como solução para suavizar pressões fiscais. Sargent (2000), ao comentar o artigo de Sims, destaca a ausência de modelos que discutam a questão da dolarização. Neste artigo, pretendemos contribuir para esta discussão. O modelo original de Cole-Kehoe serve para caracterizar uma economia dolarizada e o modelo proposto aqui, de dívida em duas moedas, para representar uma economia que emite moeda local.

Segundo Cole-Kehoe, quando a dívida em dólar pertence à zona de crise e os banqueiros internacionais não concedem mais empréstimos, a decisão ótima do governo consiste em suspender o seu pagamento. Conforme discutido acima, esta opção gera perda de bem-estar para a economia. Por outro lado, um governo que emite moeda local pode pagar somente uma fração das suas obrigações junto aos credores domésticos e, com receitas provenientes desta moratória parcial, pagar sua dívida aos banqueiros internacionais e evitar uma crise externa. Todavia, esta decisão também causa perda de bem-estar. Neste sentido, nossa contribuição ao tema de dolarização consiste em comparar o nível de bem-estar do modelo Cole-Kehoe com o bem-estar do modelo alternativo de duas moedas, considerando a possibilidade de abatimento real da dívida em moeda local que o modelo de duas dívidas oferece.

Muitos defensores da dolarização não apóiam o emprego de moeda local para gerar receitas para os governos. Eles acreditam que os governos não são capazes de utilizar o imposto inflacionário e a suspensão parcial dos pagamentos da dívida em moeda local somente em situações de crise da dívida externa. Sua influência política sobre os bancos centrais possibilita dispor destes recursos extras, mesmo não havendo pressões desfavoráveis no setor externo. A extensão do modelo Cole-Kehoe, proposta neste artigo, também permite estimar a perda de bem-estar de um governo que se comporta desta forma.

Com o intuito de simular o modelo e calcular os níveis de bem-estar mencionados, primeiramente são apresentadas as mudanças no modelo original, a fim de incorporar a moeda local e a possibilidade de suspensão parcial do pagamento da dívida. Nas etapas seguintes, os possíveis equilíbrios são caracterizados e os níveis de bem-estar calculados. 


\section{Modelo Cole-Kehoe com Moeda Local}

Cole e Kehoe desenvolvem um modelo de equilíbrio geral dinâmico e estocástico, no qual consideram a possibilidade de uma crise da dívida autorealizável ocorrer com probabilidade positiva no futuro. Entre outros resultados, os autores caracterizam uma política ótima de endividamento do governo e mostram que uma crise auto-realizável pode ocorrer, quando a dívida estiver localizada na zona de crise, e também que é ótimo, do ponto de vista de bem-estar do governo, ou reduzir a dívida ou elevar sua maturidade média, a fim de sair desta região crítica.

Comparada com o modelo original, a versão modificada incorpora a dívida em moeda local, $D$, outra variável de manchas solares, $\eta$, e uma variável de decisão do governo de fazer ou não abatimento real da dívida em moeda local, $\vartheta$. Sob outros aspectos, o modelo segue bem próximo o original. Supomos que exista um único bem nesta economia, produzido com capital e mão-deobra inelasticamente ofertada, que pode ser consumido ou poupado e que tem seu preço normalizado em US $\$ 1$, equivalente a $p_{t}$ unidades da moeda local na data $t$. Além disso, nesta economia, há três participantes (os consumidores, os banqueiros internacionais e o governo) e dois instrumentos de dívida pública (títulos denominados em moeda local, $D$, e títulos em dólar, $B$ ). Por hipótese, a dívida em dólar só é adquirida por banqueiros internacionais e a suspensão do seu pagamento é sempre total, enquanto a dívida em moeda local só é comprada pelos consumidores e seu pagamento pode ser suspenso parcialmente. A incerteza é incorporada ao modelo através de duas variáveis de manchas solares exógenas, $\zeta$ e $\eta$, que têm realização em cada período $t=0,1, \ldots$ e, por hipótese, são independentes e identicamente distribuídas no intervalo $[0,1]$, com função de distribuição uniforme. A realização da variável de manchas solares $\zeta$ indica a disposição dos banqueiros internacionais de renovarem seus créditos em dólar ao governo e a realização de $\eta$ revela o tipo de governo, se mais preocupado com a estabilidade do produto ou do preço. A probabilidade de o governo não cumprir com o pagamento de suas obrigações em dólar no período seguinte é denotada por $\pi, P[\zeta \leq \pi]=\pi$, enquanto $\xi$ é a probabilidade de o governo ser mais preocupado em evitar recessão na economia, ou seja, $P[\eta \leq \xi]$.

O modelo com duas dívidas considera também a possibilidade de o governo fazer uma moratória parcial da dívida em moeda local, embora não existam problemas de financiamento da dívida em dólar. Os banqueiros internacionais 
renovam os empréstimos, mas, ainda assim, é feito um abatimento-surpresa do valor real da dívida em moeda local, a fim de gerar receitas para o governo. Supõe-se que o setor privado atribua probabilidade $\psi \xi$ de o banco central agir desta maneira em um determinado instante. Quando a constante $\psi$ é igual a $1 / \xi$, o setor privado tem certeza de que o banco central pratica política monetária fortemente influenciado pelos interesses políticos do goveno. No outro extremo, quando a constante $\psi$ é nula, o banco central é independente e realiza moratória parcial apenas para evitar uma crise da dívida externa.

\subsection{Descrição dos participantes}

\section{Consumidores}

Existe um número infinito de indivíduos idênticos, que vivem para sempre e têm a função utilidade dada por:

$$
E \sum_{t=0}^{\infty} \beta^{t}\left[\varrho c_{t}+v\left(g_{t}\right)\right]
$$

onde $E$, é o operador esperança; $\beta$, o fator de desconto dos participantes do mercado, $0<\beta<1$; $\varrho$, o peso da utilidade do consumo privado, $c_{t}$, em relação à utilidade do bem público, $v\left(g_{t}\right) ; g_{t}$, o consumo do governo; e $v$, uma função continuamente diferenciável, estritamente côncava e monotonamente crescente, $\operatorname{com} v(0)=-\infty .^{1}$

A restrição orçamentária dos consumidores, na data $t$, é:

$$
c_{t}+k_{t+1}-k_{t}+q_{t} d_{t+1} \leq(1-\theta)\left[a_{t} f\left(k_{t}\right)-\delta k_{t}\right]+\vartheta_{t} d_{t}
$$

sendo $k_{t}$ o estoque de capital individual escolhido na data $t-1$ e $a_{t}$ o fator de produtividade, que depende de o governo ter pago ou não sua dívida em dólar. Este fator toma dois valores: 1, se o governo pagou a dívida em dólar no passado e no período corrente $\left(a_{t-1}=1\right.$ e $\left.z_{t}=1\right)$; e $\alpha$, se o governo não pagou $\left(a_{t-1}=\alpha\right.$ ou $\left.z_{t}=0\right)$. A variável $z_{t}$ indica a decisão do governo com respeito a pagar ou não sua dívida em dólar. Também admite dois valores: 1, se o governo paga e 0, se não. $O$ fator de depreciação do

\footnotetext{
${ }^{1}$ De acordo com Cole e Kehoe (1996:311), a hipótese de neutralidade ao risco no consumo privado simplifica o modelo e descarta a possibilidade de empréstimos entre os consumidores e os bancos.
} 
capital é dado por $\delta, 0 \leq \delta \leq 1$, a alíquota de impostos sobre a renda doméstica líquida corresponde a $\theta$, com $0<\theta<1$, e a função de produção, $f$, é suposta monotonamente crescente, côncava e continuamente diferenciável, satisfazendo $f(0)=0, f^{\prime}(0)=\infty, \lim _{k \rightarrow \infty} f^{\prime}(k)=0$. Além disso, cada consumidor recebe dotação de $k_{0}$ unidades do bem e $d_{0}$ unidades de dívida em moeda local na data $t=0$.

Em todo instante $t$, os consumidores designam uma parte de sua poupança para comprar títulos da dívida pública em moeda local, $d_{t+1}$, pagando $q_{t}$ unidades do bem por título, e recebem o pagamento dos títulos adquiridos no período anterior, $\vartheta_{t} d_{t}$, também em unidades do bem. A dívida em moeda local é constituída de títulos de maturidade de um período, sem cupom, que pagam, no vencimento, uma unidade do bem de consumo ao preço em moeda local vigente no período anterior. O preço de um título desta dívida, na data $t$, é dado por $\widetilde{q}_{t}$ unidades de moeda local. Sendo $p_{t}$ o preço por unidade do bem na data $t$, então o consumidor paga $q_{t}=\frac{\widetilde{q_{t}}}{p_{t}}$ unidades do bem por título da dívida em moeda local na data $t$. No período seguinte, se o governo não fizer moratória parcial da dívida em moeda local, isto é, se não fizer inflação da moeda nacional, então o consumidor receberá uma unidade inteira do bem, como o título da dívida em dólar. Neste caso, $\vartheta_{t}$ é igual a 1 . No entanto, se o governo decidir abater o valor real da dívida em moeda local, então, em lugar de uma unidade, o consumidor receberá $\vartheta_{t}=\frac{p_{t}}{p_{t+1}}=\phi, 0<\phi<1$ unidades do bem.

\section{Banqueiros internacionais}

Há um número infinito de banqueiros internacionais idênticos, que vivem para sempre e têm função utilidade

$$
E \sum_{t=0}^{\infty} \beta^{t} x_{t}
$$

e restrição orçamentária

$$
x_{t}+q_{t}^{*} b_{t+1} \leq \bar{x}+z_{t} b_{t}
$$

onde $\bar{x}$ é a dotação de bens de consumo que os banqueiros internacionais recebem em cada período, $x_{t}$ significa seu consumo deste bem e $q_{t}^{*}$ denota o preço de um título da dívida pública em dólar de um período, que paga uma 
unidade do bem de consumo em $t+1$, se não há suspensão do seu pagamento. ${ }^{2}$ Inicialmente, cada banqueiro carrega a quantidade de títulos do governo $b_{0}$.

\section{Governo}

Existe um governo benevolente, que maximiza o bem-estar dos consumidores, e sem compromisso com o pagamento da sua dívida ou com uma determinada trajetória de empréstimos e de gastos. Em cada instante $t$, o governo faz cinco escolhas:

a) do nível da dívida nova em dólar, $B_{t+1}$;

b) do nível da dívida nova em moeda local, $D_{t+1}$;

c) se paga ou não a dívida em dólar, $z_{t}$;

d) se paga parcialmente ou não a dívida em moeda local, $\vartheta_{t}$;

e) seu nível de gastos correntes, $g_{t}$.

A restrição orçamentária do governo, na data $t$, é dada por:

$$
g_{t}+z_{t} B_{t}+\vartheta_{t} D_{t} \leq \theta\left[a_{t} f\left(K_{t}\right)-\delta K_{t}\right]+q_{t}^{*} B_{t+1}+q_{t} D_{t+1}
$$

No período inicial, a oferta do governo da dívida em dólar, $B_{0}$, é igual à demanda, $b_{0}$, e a oferta do governo da dívida em moeda local, $D_{0}$, é igual à demanda por esta dívida, $d_{0}$. Além disso, o estoque de capital agregado inicial por unidade de mão-de-obra, $K_{0}$, é igual ao estoque de capital individual inicial, $k_{0}$.

Cole e Kehoe supõem que se o governo não paga a dívida em dólar em determinado período, então a produtividade, $a_{t}$, cai para $\alpha$ e permanece neste patamar daí em diante. Além de adotar esta hipótese, o modelo com duas moedas admite também que, se o governo decidir pagar somente $\phi$ unidades do bem por título, em lugar de uma unidade completa, então os consumidores terão a expectativa de que o governo pague apenas a fração $\phi$ da sua dívida em moeda local nos próximos períodos. Esta hipótese significa que, no instante da moratória parcial, o retorno de um título da dívida em moeda local é $\phi / \beta$ e não $1 / \beta$, como antes. O preço que os consumidores pagam por um título da dívida

\footnotetext{
${ }^{2}$ De acordo com Cole e Kehoe (1996:311), a hipótese de neutralidade ao risco dos banqueiros capta a idéia de que a economia doméstica é pequena em relação ao mercado financeiro internacional.
} 
em moeda local após uma moratória parcial sobre esta dívida, conforme será visto adiante, é $\phi \beta$ e este título paga $\phi$ unidades do bem no período seguinte. Logo, o retorno volta a ser $1 / \beta$ e o estoque de dívida em moeda local é como se tivesse contraído para $\phi D$.

\subsection{Equilíbrio recursivo}

A caracterização de um equilíbrio é feita de forma idêntica à do modelo Cole-Kehoe original. Tomam-se as ações dos participantes de trás para frente, de acordo com a seguinte cronologia:

- as variáveis de manchas solares $\zeta_{t}$ e $\eta_{t}$ realizam-se e o estado agregado da economia é $s_{t}=\left(K_{t}, B_{t}, D_{t}, a_{t-1}, \vartheta_{t-1}, \zeta_{t}, \eta_{t}\right)$;

- o governo, tomando como dada a equação de demanda por títulos da dívida em dólar $q_{t}^{*}=q^{*}\left(s_{t}, B_{t+1}\right)$, escolhe $B_{t+1}$ e, considerando a equação de demanda por títulos da dívida em moeda local, $q_{t}=q\left(s_{t}, B_{t+1}\right)$, escolhe $D_{t+1}$;

- os banqueiros internacionais, levando em conta $q_{t}^{*}$, decidem sobre a demanda por títulos da dívida em dólar, $b_{t+1}$, e os consumidores, considerando $q_{t}$, decidem sobre a quantidade $d_{t+1}$ que desejam adquirir da dívida em moeda local;

- dadas as escolhas dos credores, o governo decide sobre pagar a dívida em dólar, $z_{t}$, pagar parcialmente a dívida em moeda local, $\vartheta_{t}$, e, também, seus gastos correntes, $g_{t}$;

- os consumidores, tomando $a_{t}$ e $\vartheta_{t}$ como dados, escolhem $c_{t}$ e $k_{t+1}$.

\section{Os estados e o problema de maximização dos agentes}

Os consumidores escolhem em dois instantes. No início do período, conhecem seu estoque de capital trazido do período anterior, $k$, a quantidade de títulos da dívida em moeda local, $d$, o estado agregado da economia, $s$, e as ofertas pelo governo de títulos da dívida em dólar e em moeda local, $B^{\prime}$ e $D^{\prime}$. Dados $s$ e $B^{\prime}$, os consumidores têm conhecimento da equação de demanda por títulos da dívida em dólar, $q^{*}\left(s, B^{\prime}\right)$, e em moeda local, $q\left(s, B^{\prime}\right)$, e são capazes de avaliar a disposição dos banqueiros internacionais de renovarem seus créditos. Logo, ao decidirem sobre sua demanda por títulos da dívida em moeda local, $d^{\prime}$, seu estado é $\left(k, d, s, B^{\prime}, D^{\prime}\right)$ e consideram $q^{*}, q, g, z, \vartheta$ 
e $a(s, z)$ como dados. Assim sabem antecipadamente suas decisões futuras sobre $c$ e $k^{\prime}$. No segundo instante, ao decidirem sobre $c$ e $k^{\prime}$, os consumidores conhecem o preço pago pela dívida em moeda local, $q$, e também o preço pelo qual os banqueiros internacionais adquiriram títulos da dívida em dólar, $q^{*}$. Além disso, já aprenderam sobre as decisões do governo de fazer moratória total sobre a dívida em dólar, $z$, e parcial sobre a dívida em moeda local, $\vartheta$, e também sobre os gastos correntes do governo, $g$. Logo, quando o consumidor escolhe $c$ e $k^{\prime}$, seu estado é $\left(k, d, s, B^{\prime}, D^{\prime}, q^{*}, g, z, \vartheta\right) .^{3}$ A função valor do consumidor representativo corresponde a:

$$
\begin{aligned}
& V_{c}\left(k, d, s, B^{\prime}, D^{\prime}, q^{*}, g, z, \vartheta\right)= \\
& \quad=\max _{c, k^{\prime}, d^{\prime}}\left\{\varrho c+v(g)+\beta E V_{c}\left[k^{\prime}, d^{\prime}, s^{\prime}, B^{\prime}\left(s^{\prime}\right), D^{\prime}\left(s^{\prime}\right), q^{* \prime}, g^{\prime}, z^{\prime}, \vartheta^{\prime}\right]\right\}
\end{aligned}
$$

s.a.

$$
\begin{aligned}
& c+k^{\prime}-k+q d^{\prime} \leq(1-\theta)[a f(k)-\delta k]+\vartheta d \\
& c, k^{\prime} \geq 0 \\
& d^{\prime} \geq-\Delta \\
& s^{\prime}=\left(K^{\prime}\left(s, B^{\prime}, D^{\prime}, q^{*}, g, z, \vartheta\right), B^{\prime}, D^{\prime}, a(s, z), \vartheta, \zeta^{\prime}, \eta^{\prime}\right) \\
& g^{\prime}=g\left(s^{\prime}, B^{\prime}\left(s^{\prime}\right), q^{*}\left(s^{\prime}, B^{\prime}\left(s^{\prime}\right)\right), D^{\prime}\left(s^{\prime}\right), q\left(s^{\prime}, B^{\prime}\left(s^{\prime}\right)\right)\right) \\
& z^{\prime}=\left(s^{\prime}, B^{\prime}\left(s^{\prime}\right), q^{*}\left(s^{\prime}, B^{\prime}\left(s^{\prime}\right)\right), D^{\prime}\left(s^{\prime}\right), q\left(s^{\prime}, B^{\prime}\left(s^{\prime}\right)\right)\right) \\
& \vartheta^{\prime}=\left(s^{\prime}, B^{\prime}\left(s^{\prime}\right), q^{*}\left(s^{\prime}, B^{\prime}\left(s^{\prime}\right)\right), D^{\prime}\left(s^{\prime}\right), q\left(s^{\prime}, B^{\prime}\left(s^{\prime}\right)\right)\right)
\end{aligned}
$$

com $\Delta$ uma constante positiva.

$\mathrm{Na}$ sua vez de decidir sobre a quantidade de títulos da dívida em dólar que está disposto a comprar, $b^{\prime}$, o banqueiro internacional conhece a quantidade de títulos adquirida no período anterior, $b$, o estado agregado, $s$, e as ofertas, pelo governo, de títulos em dólar, $B^{\prime}$, e em moeda local, $D^{\prime}$. Além disso, toma como dados $q$ e $q^{*}$, uma vez que estes preços são revelados a partir de sua própria decisão sobre $b^{\prime}$. Assim, o estado do banqueiro representativo corresponde a $\left(b, s, B^{\prime}, D^{\prime}\right)$ e sua função valor apresenta a seguinte forma:

$$
V_{b}\left(b, s, B^{\prime}, D^{\prime}\right)=\max _{x, b^{\prime}} x+\beta E V_{b}\left(b^{\prime}, s^{\prime}, B^{\prime}\left(s^{\prime}\right), D\left(s^{\prime}\right)\right)
$$

\footnotetext{
${ }^{3}$ Seguindo a mesma especificação de Cole e Kehoe (1996:313), não se inclui q no estado do consumidor, uma vez que suas escolhas só dependem desta variável pelo seu efeito sobre $g$ e $z$.
} 
s.a.

$$
\begin{aligned}
x+q^{*}\left(s, B^{\prime}\right) b^{\prime} & \leq \bar{x}+z\left(s, B^{\prime}, q^{*}\left(s, B^{\prime}\right), D^{\prime}, q\left(s, B^{\prime}\right)\right) b \\
x & \geq 0, \quad b^{\prime} \geq-\Lambda
\end{aligned}
$$

com $\Lambda$ uma constante positiva.

O governo também toma decisão em dois momentos dentro do período. No primeiro instante, quando escolhe $B^{\prime}$ e $D^{\prime}$, o governo conhece o estado agregado, $s$, a equação de demanda por títulos da dívida em dólar, $q^{*}\left(s, B^{\prime}\right)$ e a análoga para dívida em moeda local, $q\left(s, B^{\prime}\right)$. Além disso, é de seu conhecimento suas futuras escolhas ótimas para $g\left(s, B^{\prime}, q^{*}\left(s, B^{\prime}\right), D^{\prime}, q\left(s, B^{\prime}\right)\right)$, $z\left(s, B^{\prime}, q^{*}\left(s, B^{\prime}\right), D^{\prime}, q\left(s, B^{\prime}\right)\right)$ e $\vartheta\left(s, B^{\prime}, q^{*}\left(s, B^{\prime}\right), D^{\prime}, q\left(s, B^{\prime}\right)\right)$, uma vez que só dependem do estado agregado, $s$, e de suas próprias escolhas sobre $B^{\prime}$ e $D^{\prime}$. Portanto, o governo reconhece que, através de suas ações, pode afetar os preços que os credores pagam pelas duas dívidas, $q\left(s, B^{\prime}\right)$ e $q^{*}\left(s, B^{\prime}\right)$, as decisões ótimas dos consumidores, $c\left(k, d, s, B^{\prime}, D^{\prime}, q^{*}, g, z, \vartheta\right), k^{\prime}\left(k, d, s, B^{\prime}\right.$, $\left.D^{\prime}, q^{*}, g, z, \vartheta\right)$ e $d^{\prime}\left(k, d, s, B^{\prime}, D^{\prime}\right)$ e também a produtividade da economia $a(s, z)$.

No início do período, quando o governo escolhe $B^{\prime}$ e $D^{\prime}$, toma como dados $q^{*}, q, g, z, \vartheta, c$ e $K^{\prime}$, e sua função valor corresponde a:

$$
V_{g}(s)=\max _{B^{\prime}, D^{\prime}} c\left(s, B^{\prime}, D^{\prime}, q^{*}, g, z, \vartheta\right)+v(g)+\beta E V_{g}\left(s^{\prime}\right)
$$

s.a.

$$
\begin{aligned}
g & =g\left(s, B^{\prime}, q^{*}\left(s, B^{\prime}\right), D^{\prime}, q\left(s, B^{\prime}\right)\right) \\
z & =z\left(s, B^{\prime}, q^{*}\left(s, B^{\prime}\right), D^{\prime}, q\left(s, B^{\prime}\right)\right) \\
\vartheta & =\vartheta\left(s, B^{\prime}, q^{*}\left(s, B^{\prime}\right), D^{\prime}, q\left(s, B^{\prime}\right)\right) \\
s^{\prime} & =\left\{K^{\prime}\left(s, B^{\prime}, D^{\prime}, q^{*}, g, z, \vartheta\right), B^{\prime}, D^{\prime}, a(s, z), \vartheta, \zeta^{\prime}, \eta^{\prime}\right\}
\end{aligned}
$$

Após os credores nacionais e internacionais decidirem sobre a renovação de seus empréstimos, o governo resolve se paga sua dívida em dólar, fazendo a comparação dos seus níveis de bem-estar para $z \in\{0,1\}$ e $\vartheta \in\{\phi, 1\}$. A escolha de $z$ determina o nível de produtividade, e as de $z$ e $\vartheta$ o nível de gastos correntes do governo, $g$, cuja restrição é ser positivo. As funções de política $z\left(s, B^{\prime}, q^{*}, D^{\prime}, q\right), \vartheta\left(s, B^{\prime}, q^{*}, D^{\prime}, q\right)$ e $g\left(s, B^{\prime}, q^{*}, D^{\prime}, q\right)$ são soluções para:

$$
\max _{g, z, \vartheta} c\left(s, B^{\prime}, D^{\prime}, q^{*}, g, z, \vartheta\right)+v(g)+\beta E V_{g}\left(s^{\prime}\right)
$$


s.a.

$$
\begin{aligned}
& g+z B+\vartheta D \leq \theta[a(s, z) f(K)-\delta K]+q^{*}\left(s, B^{\prime}\right) B^{\prime}+q\left(s, B^{\prime}\right) D^{\prime} \\
& g \geq 0 \\
& z=0 \text { e } \vartheta=1, \text { ou } \\
& z=1 \text { e } \vartheta=1, \text { ou } \\
& z=1 \text { e } \vartheta=\phi \\
& s^{\prime}=\left\{K^{\prime}\left(s, B^{\prime}, D^{\prime}, q, g, z, \vartheta\right), B^{\prime}, D^{\prime}, a(s, z), \vartheta, \zeta^{\prime}, \eta^{\prime}\right\}
\end{aligned}
$$

\section{Definição de um equilíbrio}

Um equilíbrio, definido para o caso de um banco central independente $(\psi=0)$, corresponde a uma lista de funções valor, $V_{c}$, para o consumidor representativo, $V_{b}$, para o banqueiro internacional representativo, e $V_{g}$, para o governo; de funções política, $c, k^{\prime}$ e $d^{\prime}$, para o consumidor, $x$ e $b^{\prime}$, para o banqueiro internacional, e $B^{\prime}, D^{\prime}, g, z$ e $\vartheta$, para o governo; de uma função preço para a dívida pública em dólar, $q^{*}$, e para a dívida em moeda local, $q$; e uma lei de movimento para $K^{\prime}$, de modo que:

a) dados $B^{\prime}, D^{\prime}, q^{*}, g, z$, e $\vartheta, V_{c}$ é a solução para o problema de maximização do consumidor representativo (1) e $c, k^{\prime}$ e $d^{\prime}$, são as escolhas ótimas;

b) dados $B^{\prime}, D^{\prime}, q^{*}, q, z$ e $\vartheta, V_{b}$ é a solução para o problema do banqueiro internacional representativo (2) e $x$ e $b^{\prime}$ são as escolhas ótimas;

c) dados $q^{*}, q, g, z, \vartheta, c$ e $K^{\prime}, V_{g}$ é a função valor para o problema do governo (3) e $B^{\prime}(s)$ e $D^{\prime}(s)$ são suas escolhas ótimas. Além disso, dados $c, K^{\prime}, V_{g}$, $B^{\prime}$ e $D^{\prime}$, as funções $g$, $z$ e $\vartheta$ são as soluções do problema (4);

d) $B^{\prime}(s) \in b^{\prime}\left(B, s, B^{\prime}, D^{\prime}\right)$;

e) $D^{\prime}(s) \in d^{\prime}\left(K, D, s, B^{\prime}, D^{\prime}\right)$;

f) $K^{\prime}\left(s, B^{\prime}, D^{\prime}, q^{*}, g, z, \vartheta\right)=k^{\prime}\left(K, D, s, B^{\prime}, D^{\prime}, q^{*}, g, z, \vartheta\right)$.

\subsection{Caracterização do equilíbrio}

Em seu modelo original, Cole e Kehoe consideram equilíbrios nos quais crises da dívida podem ocorrer com probabilidade $\pi$, dependendo da realização da variável de manchas solares $\zeta$. Se $\zeta>\pi$ e a dívida encontra-se na 
zona de crise, então os banqueiros internacionais compram nova dívida $B^{\prime} \mathrm{e}$ nenhuma crise ocorre. No entanto, se $\zeta \leq \pi$, os credores externos antecipam que o governo não honrará os pagamentos da dívida em dólar e, assim, não concedem novos empréstimos, causando, de fato, uma crise. A zona de crise de probabilidade $\pi$ é denotada pelo intervalo da dívida $\left(\bar{b}\left(k^{n}\right), \bar{B}\left(k^{\pi}, \pi\right)\right]$. O limite inferior, $\bar{b}\left(k^{n}\right)$, corresponde ao nível mais alto da dívida para o qual o governo prefere não fazer moratória da dívida, apesar de não obter novos empréstimos, dado o estoque de capital inicial, $k^{n}$. O limite superior, $\bar{B}\left(k^{\pi}, \pi\right)$, é influenciado pela probabilidade $\pi$ de os banqueiros internacionais não terem confiança no governo de cumprir com o pagamento de sua dívida e corresponde ao nível mais alto da dívida, para o qual o governo prefere não fazer moratória, após ter vendido dívida nova, $B^{\prime}$, a preço positivo.

Nesta seção, desenvolve-se um procedimento análogo, a fim de considerar equilíbrios nos quais uma crise pode ocorrer sobre a dívida em dólar com probabilidade $\pi(1-\xi)$, dependendo da realização das variáveis de manchas solares $\zeta$ e $\eta$. O modelo original de Cole e Kehoe é um caso particular do modelo de duas moedas, uma vez que não existe dívida em moeda local e a variável de manchas solares $\eta$ pode ser ignorada. Além disso, não se considera a possibilidade de uma crise da dívida em moeda local, porém os consumidores podem escolher o nível de dívida que desejam adquirir, de acordo com a equação de demanda por estes títulos, $q\left(s, B^{\prime}\right)$, que eles enfrentam. ${ }^{4}$

No modelo Cole-Kehoe com duas moedas, a zona de crise de probabilidade $\pi(1-\xi)$ é denotada por $\left(\bar{b}\left(k^{n}, D\right), \bar{B}\left(k^{\pi}, D, \pi, \xi\right)\right]$. Crises da dívida em dólar têm esta chance de ocorrer para um estado inicial da economia com as seguintes características: estoques de capital e de dívida em moeda local positivos, dívida em dólar na zona de crise e ausência de moratória da dívida em dólar e de moratória parcial da dívida em moeda local no passado. Se a dívida em dólar estiver abaixo da zona de crise, ou seja, $B \leq \bar{b}\left(k^{n}, D\right)$, a probabilidade de crise será nula e a realização das variáveis de manchas solares poderá ser ignorada. Se $B$ estiver na zona de crise, as variáveis de manchas solares desempenharão papel importante e três eventos distintos poderão ocorrer no período seguinte, dependendo do seu resultado.

\footnotetext{
${ }^{4}$ É também possivel considerar equilíbrios nos quais podem ocorrer crises sobre a dívida em moeda local, bem como sobre a divida em dólar. Neste caso, não estudado aqui, é preciso incluir uma terceira variável de manchas solares, que indique a disposição dos consumidores de adquirir nova divida em moeda local.
} 
Primeiro, se $\zeta>\pi$, os credores nacionais e internacionais crêem que o governo não fará moratória da dívida em dólar nem moratória parcial da dívida em moeda local. No entanto, se $\zeta \leq \pi$ e $\eta>\xi$, os banqueiros internacionais e os consumidores prevêem que o governo não pagará sua dívida em dólar, porque é do tipo mais preocupado com a estabilidade de preço. Terceiro, se $\zeta \leq \pi$ e $\eta \leq \xi$, o setor privado percebe que o governo não fará moratória da dívida em dólar, uma vez que se revela disposto a inflacionar a moeda local para evitar uma crise externa. Finalmente, se a dívida é maior do que o limite superior da zona de crise, também não importa a realização das variáveis de manchas solares, porque os banqueiros internacionais têm certeza de que o governo não será capaz de pagá-la e não adquirem nova dívida.

De modo a caracterizar um equilíbrio para a dívida em dólar na zona de crise, é preciso caracterizar o comportamento ótimo dos consumidores, banqueiros internacionais e governo, para um dado estado inicial $s$. Supõe-se que, no estado inicial, não tenha ocorrido nenhuma crise da dívida externa nem moratória parcial da dívida em moeda local.

\section{Comportamento ótimo de consumidores e banqueiros internacionais}

\section{Consumidores}

Supõe-se que os consumidores, ao fazerem suas escolhas no instante $t$, conheçam a decisão do governo sobre inflacionar a moeda local, $\vartheta_{t}$, e os gastos correntes do governo, $g_{t}$. Desse modo, seu problema de otimização resume-se a:

$$
\max _{c_{t}, k_{t+1}, d_{t+1}} c_{t}+\beta E c_{t+1}
$$

s.a.

$$
\begin{aligned}
c_{t}+k_{t+1}-k_{t}+q_{t} d_{t+1} & =(1-\theta)\left[a_{t} f\left(k_{t}\right)-\delta k_{t}\right]+\vartheta_{t} d_{t} \\
c_{t+1}+k_{t+2}-k_{t+1}+q_{t+1} d_{t+2} & =(1-\theta)\left[a_{t+1} f\left(k_{t+1}\right)-\delta k_{t+1}\right]+\vartheta_{t+1} d_{t+1} \\
c_{t}, c_{t+1}, k_{t+1} & \geq 0 \\
d_{t+1} & \geq-\Delta
\end{aligned}
$$

A condição de primeira ordem, com relação a $k_{t+1}$, para uma função de produção do tipo $f(k)=A k^{\nu}$ equivale à seguinte expressão:

$$
k_{t+1}=\left\{\left[\left(\frac{1}{\beta}-1\right) \frac{1}{1-\theta}+\delta\right] \frac{1}{E_{t}\left[a_{t+1}\right] A \nu}\right\}^{\frac{1}{\nu-1}}
$$


onde, $\nu$ corresponde à participação do capital na renda, e a decisão de acumulação de capital depende das expectativas dos consumidores com relação à produtividade da economia no período seguinte. Já a condição de primeira ordem com relação a $d_{t+1}$ resulta em:

$$
q_{t}=\beta E_{t}\left[\vartheta_{t+1}\right]
$$

que mostra o preço dos títulos da dívida em moeda local variando com a expectativa dos consumidores sobre haver moratória parcial da dívida em moeda local no período seguinte.

O comportamento ótimo dos consumidores, que atribuem probabilidade $\pi(1-\xi)$ para que uma crise da dívida em dólar ocorra no período seguinte, consiste em acumular capital igual a $k^{\pi \xi}$ e pagar o preço $q=\beta[1-\pi+$ $\pi(1-\xi)+\phi \pi \xi]$ por título da dívida em moeda local, desde que o consumo individual seja não-negativo. A expressão para $k^{\pi \xi}$ é dada por $E_{t}\left[a_{t+1}\right]=$ $1-\pi(1-\alpha)(1-\xi)$, substituída em (5). No caso em que o governo tenha feito anteriormente moratória parcial da dívida em moeda local e os consumidores crêem que uma crise da dívida em dólar possa ocorrer com probabilidade $\pi$ no período seguinte, então estes escolhem pagar $\beta \phi$ pela dívida em moeda local e acumulam capital igual a $k^{\pi}$, dada por $E_{t}\left[a_{t+1}\right]=1-\pi(1-\alpha)$. No entanto, se o governo fizer moratória da dívida em dólar no período corrente, então os consumidores escolherão $k_{t+1}$ igual a $k^{d}$, uma vez que a produtividade da economia se reduz para $\alpha$ deste instante em diante. Além disso, pagarão o preço $\beta$ pela dívida em moeda local, se nenhuma moratória parcial da dívida em moeda local tiver se realizado, ou pagarão o preço $\beta \phi$, caso contrário. Por fim, se os consumidores estiverem seguros de que o governo não fará moratória da dívida em dólar no período seguinte, então decidirão adquirir capital $k^{n}$, correspondente a $E_{t}\left[a_{t+1}\right]=1$, e pagarão o preço $\beta \phi$ ou $\beta$, dependendo se o governo tiver feito moratória parcial ou não.

\section{Banqueiros internacionais}

Na data $t$, o problema de otimização dos banqueiros internacionais corresponde a:

$$
\max _{x_{t}, b_{t+1}} x_{t}+\beta E\left(x_{t+1}\right)
$$

s.a.

$$
x_{t}+q_{t}^{*} b_{t+1}=\bar{x}+z_{t} b_{t}
$$


e a condição de primeira ordem resulta em

$$
q_{t}^{*}=\beta E_{t}\left[z_{t+1}\right]
$$

Logo, o preço que os banqueiros internacionais pagam pela dívida pública em dólar depende de suas expectativas acerca da decisão do governo de cumprir ou não com seus pagamentos. Se eles acreditarem que exista probabilidade $\pi(1-\xi)$ de o governo não honrar suas obrigações no período seguinte, então pagarão $q^{*}=\beta(1-\pi+\pi \xi)$. Além disso, se crerem que o governo possa fazer moratória da dívida em dólar com probabilidade $\pi$, após ter realizado moratória parcial da dívida em moeda local, então pagarão $\beta(1-\pi)$. E, nos casos extremos, se tiverem certeza de que não haverá crise, comprarão títulos da dívida em dólar por $\beta$ e, se estiverem seguros de uma crise no período seguinte, não comprarão títulos a preço positivo.

Tomando como dadas as funções $\bar{b}(K, D), \bar{B}\left(k^{\pi}, D, \pi, \phi\right)$ e $\bar{B}(K, D, \pi, \xi)$, a caracterização do comportamento ótimo de consumidores e banqueiros internacionais implica que a regra para a escolha do estoque de capital e os preços da dívida em dólar e em moeda local, em equilíbrio, são dados por:

$$
\begin{aligned}
& K^{\prime}\left(B^{\prime}\right)=\left\{\begin{array}{l}
k^{n}, \quad \text { se } B^{\prime} \leq \bar{b}\left(k^{n}, D\right) \text { e } a=1 \\
k^{\pi \xi}, \quad \text { se } \bar{b}\left(k^{n}, D\right)<B^{\prime} \leq \bar{B}\left(k^{\pi \xi}, D, \pi, \xi\right), a=1 \text { e } \vartheta=1 \\
k^{\pi}, \quad \text { se } \bar{b}\left(k^{n}, D\right)<B^{\prime} \leq \bar{B}\left(k^{\pi}, D, \pi, \phi\right), a=1 \text { e } \vartheta=\phi \\
k^{d}, \quad \text { caso contrário }
\end{array}\right. \\
& q\left(B^{\prime}\right)=\left\{\begin{array}{l}
\beta, \text { se } B^{\prime} \leq \bar{b}\left(k^{n}, D\right) \text { e } z=1 \\
\beta[1-\pi+\pi(1-\xi)+\phi \pi \xi], \text { se } \bar{b}\left(k^{n}, D\right)<B^{\prime} \leq \bar{B}\left(k^{\pi \xi}, D, \pi, \xi\right), \\
z=1 \text { e } \vartheta=1 \\
\beta \phi, \text { se } \bar{b}\left(k^{n}, D\right)<B^{\prime} \leq \bar{B}\left(k^{\pi}, D, \pi, \phi\right), z=1 \text { e } \vartheta=\phi \\
\beta \phi, \text { se } B^{\prime} \leq \bar{b}\left(k^{n}, D\right), z=1 \text { e } \vartheta=\phi \\
\beta \phi, \text { se } B^{\prime}=0, \quad z=0 \text { e } \vartheta=\phi
\end{array}\right. \\
& q^{*}\left(B^{\prime}\right)=\left\{\begin{array}{l}
\beta, \text { se } B^{\prime} \leq \bar{b}\left(k^{n}, D\right) \text { e } z=1 \\
\beta(1-\pi+\pi \xi), \text { se } \bar{b}\left(k^{n}, D\right)<B^{\prime} \leq \bar{B}\left(k^{\pi \xi}, D, \pi, \xi\right), \\
z=1 \text { e } \vartheta=1 \\
\beta(1-\pi), \text { se } \bar{b}\left(k^{n}, D\right)<B^{\prime} \leq \bar{B}\left(k^{\pi}, D, \pi, \phi\right), z=1 \text { e } \vartheta=\phi \\
0, \quad \text { caso contrário }
\end{array}\right.
\end{aligned}
$$




\section{Definição das zonas de crise de probabilidade $\pi(1-\xi)$}

Antes de caracterizar o comportamento ótimo do governo, é preciso definir a zona de crise para a dívida em dólar. Sua definição é realizada com as hipotéses de que uma crise da dívida em dólar pode ocorrer com probabilidade $\pi(1-\xi)$, a dívida em moeda local está fixa no nível $D$ e a inflação que o governo pode fazer está dada pelo fator de abatimento da dívida em moeda local, $\vartheta .{ }^{5}$

O limite inferior, $\bar{b}\left(k^{n}, D\right)$, é o nível mais elevado da dívida $B$, para o qual a seguinte restrição é satisfeita em equilíbrio:

$$
V^{n}(s, 0,0, D, \beta) \geq V^{d}(s, 0,0, D, \beta)
$$

onde $V^{n}(s, 0,0, D, \beta)$ e $V^{d}(s, 0,0, D, \beta)$, para $s=\left(k^{n}, B, D, a_{-1}, \vartheta_{-1}, \cdot, \cdot\right)$, com $a_{-1}=1, \vartheta_{-1}=1, \zeta$ e $\eta$ quaisquer, denotam os níveis de bem-estar do governo, quando ele prefere não fazer, do que fazer, respectivamente, moratória da dívida em dólar, sem que recorra à moratória parcial da dívida em moeda local e dado que não recebe novos empréstimos dos credores internacionais. O inverso da restrição (6) é a condição de não-empréstimos.

O limite superior, $\bar{B}\left(k^{\pi \xi}, D, \pi, \xi\right)$, é o nível mais elevado da dívida em dólar para o qual os banqueiros internacionais emprestam em equilíbrio, apesar da probabilidade $\pi(1-\xi)$ de uma crise da dívida externa ocorrer no período seguinte. É calculado como o nível mais alto da dívida em dólar, tal que as seguintes duas restrições são satisfeitas simultaneamente:

$$
\begin{aligned}
& V^{\pi \xi}\left(s, B^{\prime}, q^{*}\left(B^{\prime}\right), D, q\left(B^{\prime}\right)\right) \geq V^{d}\left(s, B^{\prime}, q^{*}\left(B^{\prime}\right), D, q\left(B^{\prime}\right)\right) \\
& V^{\pi}\left(s, B^{\prime}, q^{*}\left(B^{\prime}\right), D, \phi \beta\right) \geq V^{d}\left(s, B^{\prime}, q^{*}\left(B^{\prime}\right), D, \phi \beta\right)
\end{aligned}
$$

onde $V^{\pi \xi}\left(s, B^{\prime}, q^{*}\left(B^{\prime}\right), D, q\left(B^{\prime}\right)\right)$ e $V^{d}\left(s, B^{\prime}, q^{*}\left(B^{\prime}\right), D, q\left(B^{\prime}\right)\right)$, dado o estado $s=\left(k^{\pi \xi}, B, D, a_{-1}, \vartheta_{-1}, \zeta, \cdot\right)$, com $a_{-1}=1, \vartheta_{-1}=1, \zeta>\pi$, e $\eta$ qualquer, denotam os níveis de bem-estar do governo não fazer e fazer moratória da dívida em dólar, respectivamente, e não recorrer à moratória parcial da dívida em moeda local em ambos os casos, ou seja, quando o governo escolhe $z=1$ e $\vartheta=1$, em lugar de $z=0$ e $\vartheta=1$. Esta condição garante que, para o estado inicial $s=\left(k^{\pi \xi}, B, D, 1,1, \zeta, \cdot\right)$, $\operatorname{com} \zeta>\pi$, o governo pagará sua dívida em

\footnotetext{
${ }^{5}$ A caracterização dos limites superior e inferior da zona de crise pode ser obtida diretamente dos autores.
} 
dólar e em moeda local completamente, desde que consiga vender nova dívida em dólar ao preço $q^{*}\left(B^{\prime}\right)$ e nova dívida em moeda local ao preço $q^{*}\left(B^{\prime}\right)$.

A restrição (8) significa que o governo prefere pagar a dívida em dólar e fazer moratória parcial da dívida em moeda local, a não pagar sua dívida em dólar e evitar a moratória parcial da dívida em moeda local, dado o estado $s=\left(k^{\pi \xi}, B, D, 1,1, \zeta, \eta\right)$, com $\zeta \leq \pi$ e $\eta \leq \xi$, desde que venda nova dívida em dólar ao preço $q^{*}\left(B^{\prime}\right)$ e dívida em moeda local ao preço $\beta \phi$. Os níveis de bemestar $V^{\pi}\left(s, B^{\prime}, q^{*}\left(B^{\prime}\right), D, \phi \beta\right)$ e $V^{d}\left(s, B^{\prime}, q^{*}\left(B^{\prime}\right), D, \beta \phi\right)$ resultam da decisão do governo de escolher $z=1$ e $\vartheta=\phi$ contra $z=0$ e $\vartheta=1$, respectivamente.

\section{Decisões ótimas do governo}

Seguindo o mesmo procedimento de Cole e Kehoe (2000:101-2), analisa-se a decisão do governo nas duas regiões da dívida em dólar: abaixo da zona de crise e na zona de crise. Mantêm-se as hipóteses de que o nível de endividamento do governo em moeda local é fixo e o abatimento da dívida em moeda local, uma fração, $v$, já conhecida.

Quando a dívida em dólar está abaixo da zona de crise, ou seja, $B \leq$ $\bar{b}\left(k^{n}, D\right)$, não é possível ocorrer uma crise. Para que não haja crise da dívida em dólar no período seguinte, a política do governo com relação a $B^{\prime}$ é tal que induz os consumidores a acumularem capital $k^{\prime}=k^{n}$ e pagarem $\beta$ por título da dívida em moeda local, e os banqueiros internacionais a comprarem títulos em dólar por $\beta$. Assim, quando a dívida em dólar encontra-se abaixo da zona de crise e não houve moratória parcial da dívida em moeda local, então a solução do problema de otimização do governo $B^{\prime}$ tem de satisfazer a condição $B^{\prime} \leq \bar{b}\left(k^{n}, D\right)$.

Esta solução é obtida a partir do problema de otimização do governo para $B_{t+1}$, dados $B_{t}, B_{t+2}, D$, e $K_{t}$ e $K_{t+1}$ iguais a $k^{n}$, a saber:

$$
\max _{B_{t+1}} \beta^{t} v\left(g_{t}\right)+\beta^{t+1} v\left(g_{t+1}\right)
$$

s.a.

$$
\begin{aligned}
& g_{t}=\theta y^{n}+\beta B_{t+1}-B_{t}-(1-\beta) D \\
& g_{t+1}=\theta y^{n}+\beta B_{t+2}-B_{t+1}-(1-\beta) D \\
& g_{t}, g_{t+1}>0 \\
& y^{n}=f\left(k^{n}\right)-\delta k^{n}
\end{aligned}
$$


cuja condição de primeira ordem é dada por:

$$
v^{\prime}\left(g_{t}\right)=v^{\prime}\left(g_{t+1}\right)
$$

que implica $g_{t}=g_{t+1}$ e $B^{\prime}=B \leq \bar{b}\left(k^{n}, D\right)$.

Portanto, para a dívida inicial $B_{0} \leq \bar{b}\left(k^{n}, D\right)$, a escolha ótima de $B^{\prime}$ é $B_{0}$ e, em todos os instantes em que a dívida inicial encontra-se abaixo da zona de crise, o consumo individual é igual a $(1-\theta) y^{n}+(1-\beta) D$ e o consumo do governo equivale a $\theta y^{n}-(1-\beta) B_{0}-(1-\beta) D$. Logo, o bem-estar do governo, quando sua dívida inicial está na zona de ausência de crise, corresponde à seguinte expressão:

$V^{n}\left(s, B_{0}, \beta, D, \beta\right)=\frac{1}{1-\beta}\left\{\varrho\left[(1-\theta) y^{n}+(1-\beta) D\right]+v\left[\theta y^{n}-(1-\beta) B_{0}-(1-\beta) D\right]\right\}$

para o estado $s=\left(k^{n}, B_{0}, D, 1,1, \cdot, \cdot\right)$. O bem-estar do governo, correspondente à decisão de fazer moratória da dívida em dólar e não fazer moratória parcial da dívida em moeda local, dado o estado agregado $s$, equivale a:

$$
\begin{aligned}
& V^{d}\left(s, B_{0}, \beta, D, \beta\right)=\varrho\left\{(1-\theta)\left[\alpha f\left(k^{n}\right)-\delta k^{n}\right]-k^{d}+k^{n}+(1-\beta) D\right\}+ \\
& \quad+v\left\{\theta\left[\alpha f\left(k^{n}\right)-\delta k^{n}\right]+\beta B_{0}-(1-\beta) D\right\}+ \\
& \quad+\frac{\beta}{1-\beta}\left\{\varrho\left\{(1-\theta)\left[\alpha f\left(k^{d}\right)-\delta k^{d}\right]+(1-\beta) D\right\}+\right. \\
& \left.\quad+v\left[\theta\left(\alpha f\left(k^{d}\right)-\delta k^{d}\right)-(1-\beta) D\right]\right\}
\end{aligned}
$$

Com estas duas expressões para o bem-estar do governo, é possível mostrar que o governo sempre prefere não fazer moratória da dívida em dólar, quando a dívida inicial está na zona de ausência de crise. Assim, o governo sempre escolhe $z$ e $\vartheta$ iguais a 1 .

O próximo passo consiste em caracterizar o comportamento ótimo do governo, quando sua dívida inicial encontra-se na zona de crise, admitindo-se que nenhuma das duas restrições (7) e (8) sejam ativas. Suponha que o estoque de capital inicial, $K$, seja $k^{\pi \xi}$ e a dívida inicial, $B$, seja tal que $B>\bar{b}\left(k^{n}, D\right)$. O governo tem as seguintes opções com relação a $B^{\prime}$ : fazer moratória; reduzir a dívida para $\bar{b}\left(k^{n}, D\right)$ em $T$ períodos, se nenhuma crise ocorrer; ou nunca reduzi-la. A escolha ótima é determinada pelo maior dos níveis de bem-estar esperados, entre as três opções. 
A solução do problema de otimização do governo para $B^{\prime}, \operatorname{dados} B>$ $\bar{b}\left(k^{n}, D\right), z=1, \vartheta=1$ e probabilidade $\pi(1-\xi)$ de moratória da dívida em dólar no próximo período, resulta na seguinte condição de primeira ordem a ser satisfeita:

$$
v^{\prime}\left(g_{t}\right)(1-\pi+\pi \xi)=(1-\pi) v^{\prime}\left(g_{t+1}^{n}\right)+\pi \xi v^{\prime}\left(g_{t+1}^{d p}\right)
$$

onde

$$
\begin{aligned}
& g_{t}=\theta y^{\pi \xi}-B_{t}+\beta(1-\pi+\pi \xi) B_{t+1}-D+\beta[1-\pi+\pi(1-\xi)+\phi \pi \xi] D \\
& g_{t+1}^{n}=\theta y^{\pi \xi}-B_{t+1}+\beta(1-\pi+\pi \xi) B_{t+2}-D+\beta[1-\pi+\pi(1-\xi)+\phi \pi \xi] D \\
& g_{t+1}^{d p}=\theta y^{\pi \xi}-B_{t+1}+\beta(1-\pi) B_{t+2}-\phi(1-\beta) D \\
& y^{\pi \xi}=f\left(k^{\pi \xi}\right)-\delta k^{\pi \xi}
\end{aligned}
$$

No modelo Cole-Kehoe original, o governo mantém um nível constante de gastos, quando uma crise não ocorre no período corrente, mas é possível no instante seguinte. Com este resultado, obtém-se uma expressão analítica para o bem-estar do governo, quando este decide reduzir sua dívida inicial em $T$ etapas até atingir o patamar $\bar{b}\left(k^{n}\right)$. A condição que garante o nível de gastos constante em todos os períodos é dada pela condição de primeira ordem do problema do governo, quando se supõe $\xi$ nulo.

No entanto, com $\xi$ positivo, até o governo atingir a dívida $\bar{b}\left(k^{n}, D\right)$, os gastos do governo não são constantes. Portanto, a expressão analítica para o nível de bem-estar esperado pelo governo ao reduzir sua dívida para $\bar{b}\left(k^{n}, D\right)$ em $T$ períodos é mais complexa do que a obtida no modelo original ColeKehoe. ${ }^{6}$

\subsection{Bem-estar do governo}

O principal objetivo deste artigo é caracterizar o bem-estar, quando a dívida em moeda local é incluída no modelo, e compará-lo com o bem-estar do modelo Cole-Kehoe original. O bem-estar no modelo original considera que toda a dívida está constituída por títulos em dólar, enquanto no modelo com duas dívidas a dívida está composta por títulos em dólar e em moeda

\footnotetext{
${ }^{6}$ Condições que os níveis de endividamento intermediários devem atender, quando o governo decide reduzir sua dívida inicial para $\bar{b}\left(k^{n}, D\right)$ em até três períodos, podem ser obtidas diretamente dos autores.
} 
local. Esta comparação é feita supondo-se que a dívida em moeda local, $D$, é fixa e que o governo siga uma política de endividamento estacionário para a dívida em dólar, $B$. Portanto, nos exercícios numéricos com o modelo de duas dívidas, o governo não escolhe $D_{t+1}$ e $B_{t+1}$ a fim de maximizar seu bem-estar.

\section{Abaixo da zona de crise}

Para níveis da dívida em dólar inferiores a $\bar{b}\left(k^{n}, D\right)$ a probabilidade de crise da dívida em dólar é nula. Logo, o bem-estar do governo é aquele que ele obtém mantendo o nível de endividamento estacionário e sem fazer moratória, nem sobre a dívida externa, nem parcial sobre a interna. Neste caso, a hipótese de endividamento estacionário é a política ótima do governo para a dívida em dólar, conforme resultado do modelo Cole-Kehoe, na ausência de incerteza. Dado o estado inicial $s=\left(k^{n}, B, D, a_{-1}, \vartheta_{-1}, \zeta, \eta\right)$, com $a_{-1}=1, \vartheta_{-1}=1$, e $\zeta$ e $\eta$ quaisquer, o bem-estar do governo, para a dívida em dólar $B \leq \bar{b}\left(k^{n}, D\right)$, é dado por:

$$
\begin{aligned}
& V^{n}(s, B, \beta, D, \beta)= \\
& \quad=\frac{1}{1-\beta}\left\{\varrho\left[(1-\theta) y^{n}+(1-\beta) D\right]^{+} v\left[\theta y^{n}-(1-\beta) B-(1-\beta) D\right]\right\}
\end{aligned}
$$

com, $y^{n}=f\left(k^{n}\right)-\delta k^{n}$.

O bem-estar do governo, no modelo Cole-Kehoe original, é uma especificação mais simplificada do que a do modelo com duas dívidas. Para o estado inicial $s=\left(k^{n}, B, a_{-1}, \zeta\right)$, com $a_{-1}=1$ e $\zeta$ qualquer, o bem-estar do governo corresponde a:

$$
V^{n}(s, B, \beta)=\frac{1}{1-\beta}\left\{\varrho(1-\theta) y^{n}+v\left[\theta y^{n}-(1-\beta) B\right]\right\}
$$

A presença de moeda local torna possível que os bancos centrais sofram pressões políticas para aumentar as receitas do governo e fazer moratória parcial da dívida em moeda local, apesar de os banqueiros internacionais não dificultarem a rolagem da dívida em dólar. O modelo com duas dívidas admite que o governo pode decidir pressionar politicamente o banco central para que faça inflação, sem que haja crise da dívida externa. Em um instante qualquer e antes de ser revelado o tipo de banco central, o setor privado atribui probabilidade $\psi \xi$ de o banco central sofrer pressões políticas por parte do governo. 
Um banco central que age desta forma é caracterizado pelo parâmetro positivo $\psi$, enquanto um banco central que não se desvia de seu comportamento independente é caracterizado por $\psi$ nulo. Logo, em um instante qualquer, dado o estado inicial $s=\left(k^{n}, B, D, a_{-1}, \vartheta_{-1}, \zeta, \eta\right)$, com $B \leq \bar{b}\left(k^{n}, D\right), a_{-1}=1$, $\vartheta_{-1}=1, \zeta$ e $\eta$ quaisquer e $\psi \xi$ positivo, o bem-estar do governo é dado por:

$V^{n \psi}(s, B, \beta, D, \beta)=(1-\psi \xi) \frac{1}{(1-\beta)} u^{n}\left(k^{n}\right)+\psi \xi\left[u^{\psi}\left(k^{n}\right)+\frac{\beta}{(1-\beta)} u^{d p}\left(k^{n}\right)\right]$

onde

$$
\begin{aligned}
& u^{n}\left(k^{n}\right)=\varrho\left[(1-\theta) y^{n}+(1-\beta) D\right]+v\left[\theta y^{n}-(1-\beta) B-(1-\beta) D\right] \\
& u^{\psi}\left(k^{n}\right)=\varrho\left[(1-\theta) y^{n}+(\phi-\beta) D\right]+v\left[\theta y^{n}-(1-\beta) B-(\phi-\beta) D\right] \\
& u^{d p}\left(k^{n}\right)=\varrho\left[(1-\theta) y^{n}+\phi(1-\beta) D\right]+v\left[\theta y^{n}-(1-\beta) B-\phi(1-\beta) D\right]
\end{aligned}
$$

Neste caso, se $\psi \xi$ for nulo, então obter-se-á a mesma expressão de $V^{n}(s, B$, $\beta, D, \beta)$.

\section{Na zona de crise}

Para níveis da dívida em dólar acima de $\bar{b}\left(k^{n}, D\right)$, há probabilidade positiva de crise da dívida em dólar e agora também está disponível o recurso da moratória da dívida em moeda local para conter uma crise externa. Dado o estado inicial $s=\left(k^{\pi \xi}, B, D, 1,1, \zeta, \eta\right), B>\bar{b}\left(k^{n}, D\right)$, o bem-estar do governo antes da realização das variáveis de manchas solares é dado pelo valor esperado dos três níveis de bem-estar esperados, de acordo com a possível realização das mesmas. Sua expressão corresponde a:

$$
\begin{aligned}
V^{\pi \xi}(s) & =(1-\pi) V^{\pi \xi}(s, B, \beta(1-\pi+\pi \xi), D, \beta[1-\pi+\pi(1-\xi)+\phi \pi \xi])+ \\
+ & \pi \xi\left[u^{d p}\left(k^{\pi \xi}\right)+\beta V^{\pi}\left(\left(k^{\pi}, B, D, 1, \phi, \zeta, \cdot\right), B, \beta(1-\pi), D, \beta \phi\right)\right]+ \\
+ & \pi(1-\xi)\left[u^{d}\left(k^{\pi \xi}\right)+\beta w_{d D}\right]
\end{aligned}
$$

onde as expressões para $V^{\pi \xi}(s, B, \beta(1-\pi+\pi \xi), D, \beta[1-\pi+\pi(1-\xi+\phi \pi \xi))$, $u^{d}\left(k^{\pi \xi}\right), w_{d D}, u^{d p}\left(k^{\pi \xi}\right)$ e $V^{\pi}\left(\left(k^{\pi}, B, D, 1, \phi, \zeta, \cdot, B, \beta(1-\pi), D, \beta \phi\right)\right.$ encontram-se no anexo. 
O bem-estar $V^{\pi \xi}(s, B, \beta(1-\pi+\pi \xi), D, \beta[1-\pi+\pi(1-\xi)+\phi \pi \xi])$ é aquele alcançado quando o governo decide não fazer moratória nem sobre a dívida externa, nem sobre a interna no instante inicial e enfrenta probabilidade $\pi(1-\xi)$ de uma crise da dívida externa ocorrer no período seguinte, após ter vendido dívida em dólar ao preço $\beta(1-\pi+\pi \xi)$ e dívida em moeda local ao preço $\beta[1-\pi+\pi(1-\xi+\phi \pi \xi)]$. Já $V^{\pi}\left(\left(k^{\pi}, B, D, 1, \phi, \zeta, \cdot\right), B, \beta(1-\pi), D, \beta \phi\right)$ é o nível de bem-estar esperado do governo que enfrenta probabilidade $\pi$ de uma moratória da dívida em dólar em todos os instantes, que escolher não fazer moratória da dívida em dólar, levando em conta que uma moratória parcial da dívida em moeda local já foi realizada anteriormente. E o bem-estar $w_{d D}$ é aquele que o governo alcança quando tiver feito moratória da dívida externa.

O nível de bem-estar do modelo Cole-Kehoe original é apenas um caso especial do modelo com duas moedas, quando se supõe que $\xi, \bar{x}_{D}, D_{t}$ e $D_{t+1}$ são nulos. Para o estado inicial $s=\left(k^{\pi}, B, a_{-1}, \zeta\right)$, com $B>b\left(k^{n}\right), a_{-1}=1$, e $\zeta>\pi$, o bem-estar do governo equivale à expressão:

$$
V^{\pi}(s)=(1-\pi) V^{\pi}(s, B, \beta(1-\pi))+\pi V^{d}(s, B, \beta(1-\pi))
$$

onde

$$
\begin{aligned}
& V^{d}(s, B, \beta(1-\pi))=u^{d}\left(k^{\pi}\right)+\frac{\beta}{1-\beta} u^{d}\left(k^{d}\right) \\
& V^{\pi}(s, B, \beta(1-\pi))=\frac{1}{1-\beta(1-\pi)} u^{\pi}\left(k^{\pi}\right)+\frac{\beta \pi}{1-\beta(1-\pi)} u^{d}\left(k^{\pi}\right)+ \\
& \quad+\frac{\beta^{2} \pi}{(1-\beta)[1-\beta(1-\pi)]} u^{d}\left(k^{d}\right) \\
& u^{\pi}\left(k^{\pi}\right)=\varrho(1-\theta)\left[f\left(k^{\pi}\right)-\delta k^{\pi}\right]+v\left\{\theta\left[f\left(k^{\pi}\right)-\delta k^{\pi}\right]-[1-\beta(1-\pi)] B\right\} \\
& u^{d}\left(k^{\pi}\right)=\varrho\left\{(1-\theta)\left[\alpha f\left(k^{\pi}\right)-\delta k^{\pi}\right]-k^{d}+k^{\pi}\right\}+v\left\{\theta\left[\alpha f\left(k^{\pi}\right)-\delta k^{\pi}\right]\right\} \\
& u^{d}\left(k^{d}\right)=\varrho(1-\theta)\left[\alpha f\left(k^{d}\right)-\delta k^{d}\right]+v\left\{\theta\left[\alpha f\left(k^{d}\right)-\delta k^{d}\right]\right\}
\end{aligned}
$$

Por último, supondo que o governo possa surpreender o setor privado com uma inflação surpresa da moeda local, $\psi \xi$ é positivo e, dado o estado inicial $s=\left(k^{\pi \xi}, B, D, 1,1, \zeta, \eta\right)$, o nível de bem-estar esperado do governo equivale a: 


$$
\begin{aligned}
& V^{\pi \xi}(s, \psi)=\pi \xi\left[u^{d p}\left(k^{\pi \xi}\right)+\beta V^{\pi}\left(\left(k^{\pi}, B, D, 1, \phi, \zeta, \cdot\right), B, \beta(1-\pi), D, \beta \phi\right)\right]+ \\
& \quad+\pi(1-\xi)\left[u^{d}\left(k^{\pi \xi}\right)+\beta w_{d D}\right]+(1-\pi) \psi \xi\left[u^{d p}\left(k^{\pi \xi}, \psi\right)+\right. \\
& \left.\quad+\beta V^{\pi}\left(\left(k^{\pi}, B, D, 1, \phi, \zeta, \cdot\right), B, \beta(1-\pi), D, \beta \phi\right)\right]+ \\
& \quad+(1-\pi)(1-\psi \xi) V^{\pi \xi}(s, B, \beta(1-\pi+\pi \xi), D, \beta[1-\pi+\pi(1-\xi)+\phi \pi \xi])
\end{aligned}
$$

onde

$$
\begin{aligned}
& u^{d p}\left(k^{\pi \xi}, \psi\right)=\varrho\left\{(1-\theta) y^{\pi \xi}-k^{\pi}+k^{\pi \xi}+\right. \\
& \quad+\{\phi-\beta[1-\pi+\pi(1-\xi)+\phi \pi \xi]\} D\}+ \\
& \quad+v\left\{\theta y^{\pi \xi}-[1-\beta(1-\pi+\pi \xi)] B-\{\phi-\beta[1-\pi+\pi(1-\xi)+\phi \pi \xi]\} D\right\}
\end{aligned}
$$

Se não há inflação-surpresa em um instante inicial qualquer, isto é, $\psi$ é nulo, então os credores não têm expectativa de que ela possa ocorrer no período seguinte também (se não, a inflação deixaria de ser surpresa). Desse modo, o bem-estar esperado é igual ao da realização favorável das duas variáveis de manchas solares.

\section{Exercício Numérico}

O objetivo desta seção consiste em avaliar o bem-estar do governo quando há probabilidade positiva de moratória da dívida externa e probabilidade positiva desta moratória ser evitada mediante a inflação da moeda local. Este bem-estar é obtido com o emprego do modelo Cole-Kehoe de duas dívidas e política monetária sob controle nacional. Nas simulações, admite-se que a dívida em moeda local relativa ao PIB está fixa e que o endividamento em dólar é estacionário. Dessa forma, o governo não escolhe otimamente sua dívida. Em vista desta suposição, a análise dos resultados é realizada com cautela. Aplica-se este modelo para a economia brasileira no período recente.

\subsection{Os parâmetros para a economia brasileira}

Os parâmetros são escolhidos de tal forma que o período inicial reproduza a situação no Brasil entre junho de 1999 e maio de 2001. Este intervalo de 
dois anos equivale ao prazo médio da dívida do governo federal brasileiro, referente aos títulos negociáveis e nas mãos do público. ${ }^{7}$ Admite-se que a maturidade média da dívida em moeda local seja descrita pelo prazo médio da dívida indexada à taxa Selic, enquanto o prazo médio da dívida em dólar, seja dado pelo da dívida indexada ao dólar. Ambas as maturidades médias são aproximadamente iguais a 24 meses.

Valores iguais aos usados por Cole e Kehoe (1996) para o México são designados para a função de produção e o coeficiente de aversão ao risco relativo, risk. A função de produção é especificada por $f(k)=A k^{\nu}$ e risk é igual a 1, resultando em uma função logarítmica para a utilidade dos gastos correntes do governo, $v, v(g)=l n g$. Além disso, Cole e Kehoe (1996) admitem que, quando o governo não paga sua dívida, a produção mexicana cai para 95\% no período após a crise. Desse modo, o coeficiente $\alpha$ equivale a 0,95 . Esta mesma hipótese é usada para o Brasil. Já a alíquota de impostos sobre as receitas líquidas, $\theta$, corresponde à carga tributária total, como percentagem do PIB. Atribui-se a este parâmetro a fração 0,30 do PIB no biênio, próxima aos dados de 29,33\%, para 1998 e $31,67 \%$, para o ano seguinte. ${ }^{8}$ A participação do capital na renda (capital share) corresponde a 0,5 , conforme utilizado por Ellery e outros (2000).

De acordo com Cole e Kehoe, a probabilidade de não pagar a dívida em dólar, $\pi$, está baseada na taxa de juros da dívida indexada ao dólar e de curto prazo do governo mexicano. A expressão utilizada para calcular esta probabilidade corresponde a:

$$
\pi=1-\left[\left(\frac{1+r^{*}}{1+r}\right)^{\frac{1}{n}}\right]
$$

onde $r$ é a taxa de juros até a maturidade, anualizada e referente ao retorno, em dólares, do título do país que pode suspender seus pagamentos, $r^{*}$, a taxa de juros até a maturidade, anualizada, dos títulos do Tesouro dos EUA e $n$, o números de períodos que constituem um ano. Para o Brasil, $r$ é relativa às Notas do Banco Central do Brasil, série E (NBCE), com maturidade de dois

\footnotetext{
${ }^{7}$ Os dados de prazo médio são obtidos em http://www.bcb.gov.br/htms/infecon/demab. As informações referem-se ao período de fevereiro de 2000 a julho de 2001, porque mudanças foram realizadas em seu cálculo em fevereiro de 2000.

${ }^{8}$ Dados de contas nacionais, do IBGE, obtidos em http://www.ipeadata.gov.br e acessados em 21-8-2001.
} 
anos e vendidas em ofertas públicas pelo Banco Central. ${ }^{9}$ As taxas de juros das NBCE e das notas do Tesouro americano, com características similares, estão apresentadas na tabela 1 , inclusive a estimativa de $\pi .^{10}$

Portanto, dado o horizonte de dois anos, o setor privado espera que o governo não pague a dívida em dólar com probabilidade variando de $4 \%$ a $8 \%$, durante o ano de 2000 e o primeiro semestre de 2001. Nas simulações, emprega-se $\pi$ igual a 0,06 , que corresponde à média.

De acordo com Cole e Kehoe (1996), o parâmetro $\beta$ é equivalente ao preço de um título sem risco, que paga uma unidade do bem de consumo após um período. Cole e Kehoe empregam este mesmo parâmetro para representar o fator de desconto do governo mexicano, que é calculado como base no rendimento até a maturidade dos títulos do Tesouro americano com maturidade inferior a um ano (Treasury bills). Na simulação para o Brasil, utiliza-se o mesmo procedimento adotado por Cole e Kehoe. Assim, o cálculo de $\beta$ corresponde ao inverso da rentabilidade real até a maturidade das notas do Tesouro americano, com maturidade de dois anos, deflacionadas pela expectativa de inflação do índice de preços ao consumidor dos EUA, publicada na revista The Economist. ${ }^{11}$ Desse modo, considera-se que os credores têm expectativas racionais quando avaliam a rentabilidade real dos títulos que adquirem. Com dados de previsão de fevereiro de 1999 para a inflação em 1999 a 2000 e a rentabilidade, neste biênio, de 9,150\%, das notas do Tesouro americano de maturidade de dois anos, adquiridas em 1o de fevereiro de 1999, estima-se $\beta$ igual a 0,955. Com as previsões de março de 1999 para a inflação de 1999 a 2000 e rentabilidade de 10,018\% dos títulos americanos comprados em 1ํㅡㅁ de março de 1999, resulta que $\beta$ é igual a 0,948. A tabela 2 mostra algumas estimativas obtidas para $\beta$ com este procedimento. $\mathrm{O}$ valor de $\beta$ empregado nas simulações é 0,95 .

\footnotetext{
${ }^{9}$ NBCE é um título emitido pelo Banco Central do Brasil (BCB), com valor atualizado pelo dólar e pagamento de cupom a cada seis meses, para maturidades acima de seis meses. A rentabilidade líquida corresponde à rentabilidade bruta multiplicada por $(1-\tau)$, onde $\tau$ é a alíquota de $20 \%$, do imposto sobre o rendimento produzido a partir de 1- de janeiro de 1998 , por aplicação financeira de renda fixa, de acordo com o Decreto n-3.000, de 26 de março de 1999 (Receita Federal, 2001).

${ }^{10}$ Taxas de juros até a maturidade dos títulos do Tesouro dos EUA são obtidas em http://www.publicdebt.treas.gov.

${ }^{11}$ Todos os meses a revista The Economist faz um levantamento das previsões econômicas, realizadas por instituições financeiras para dois anos, e calcula a sua média, incluindo as do IPC dos EUA.
} 


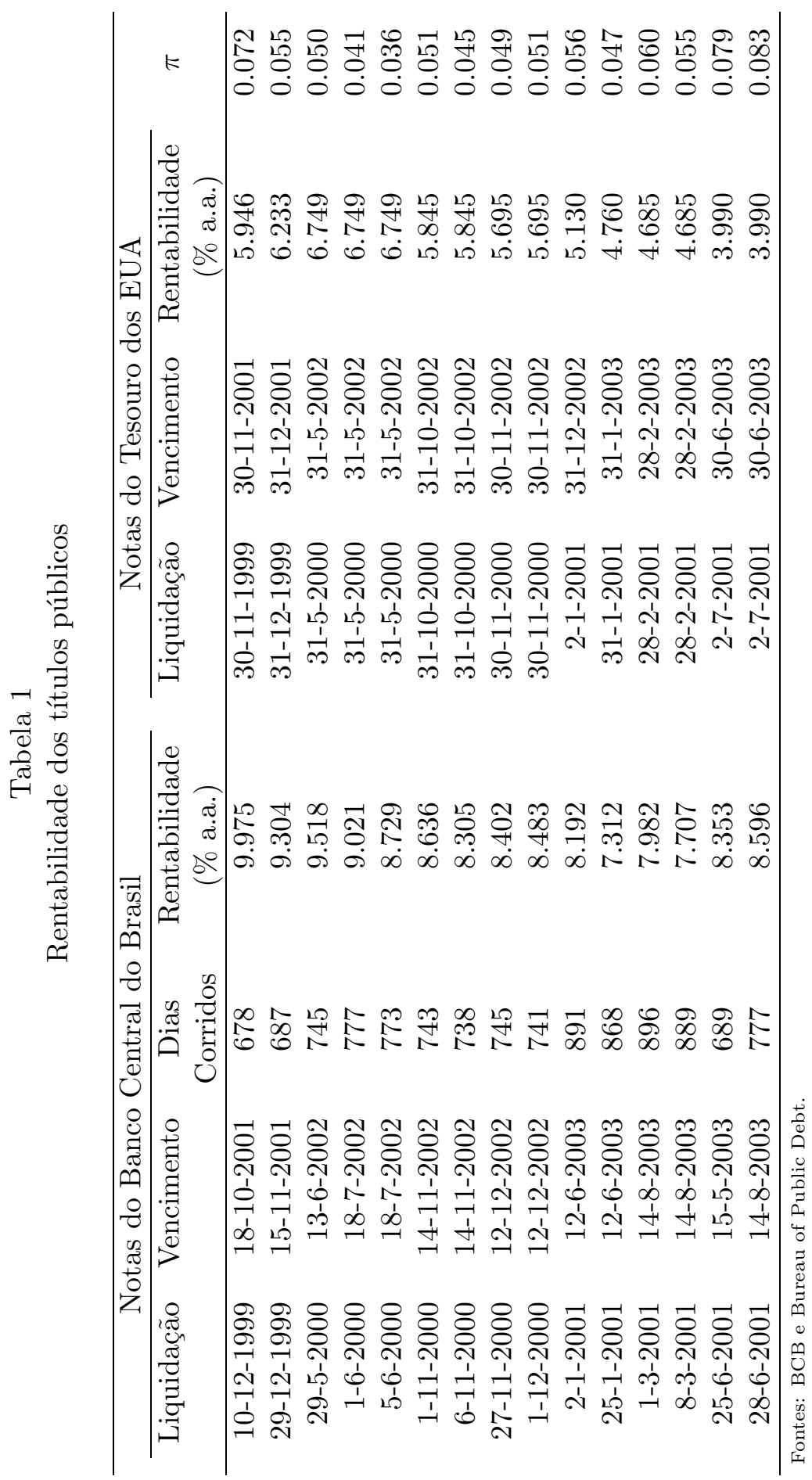


Tabela 2

Estimativas do fator de desconto

\begin{tabular}{|c|c|c|c|c|c|c|c|c|}
\hline \multicolumn{4}{|c|}{ Notas do Tesouro dos EUA } & \multicolumn{4}{|c|}{$\frac{\text { IPC - EUA }}{\text { Previsões de inflação }(\%)}$} & \multirow[t]{2}{*}{ Beta } \\
\hline $\begin{array}{l}\text { Data de } \\
\text { emissão }\end{array}$ & $\begin{array}{r}\text { Data de } \\
\text { maturidade }\end{array}$ & $\frac{\text { Renta }}{\% \text { a.a. }}$ & $\frac{\text { bilidade }}{\text { no biênio }}$ & Previsõe & $\begin{array}{c}\text { es de in } \\
1999 / \\
2000\end{array}$ & $\begin{array}{c}\text { flação ( } \\
2000 / \\
2001\end{array}$ & $\begin{array}{l}\% \text { \%) } \\
2000 / \\
2002\end{array}$ & \\
\hline $1-2-1999$ & $31-1-2001$ & 4.575 & 9.150 & Fev. 1999 & 4.2 & & & 0.955 \\
\hline 1-3-1999 & $28-2-2001$ & 5.009 & 10.018 & Mar. 1999 & 4.3 & & & 0.948 \\
\hline $29-2-2000$ & $28-2-2002$ & 6.590 & 13.180 & Mar. 2000 & & 5.4 & & 0.931 \\
\hline $28-2-2001$ & $28-2-2003$ & 4.685 & 9.370 & Mar. 2001 & & & 5.0 & 0.960 \\
\hline
\end{tabular}

Fontes: Bureau of Public Debt e the Economist.

O fator de depreciação, $\delta$, equivale a aproximadamente $24 \%$ para o período de dois anos e é obtido como o resíduo da condição de que a razão capitalproduto seja 3,0. ${ }^{12}$ Já a produtividade total dos fatores, $A$, é considerada um fator de escala na simulação, de modo que o limite superior da zona de crise pertença ao intervalo $(1,0 ; 1,2)$ para a maturidade média até 10 anos. Seu valor é escolhido igual a 1,3 .

Para estimar o bem-estar do governo, ambos os níveis de endividamento do governo são especificados. A dívida do setor público, em moeda local, $D$, é equivalente à dívida interna líquida do setor público, excluída a fração de títulos indexados ao dólar. A fração de $D$ no PIB é aproximadamente igual a $30 \%$ durante os meses de junho de 1999 a maio de 2001, conforme se observa na tabela 3. Por outro lado, a dívida do setor público em dólar, $B$, corresponde à dívida externa do setor público (menos reservas internacionais), mais a dívida indexada ao dólar. Sua participação no PIB, para o mesmo período, é, em média, de 20\%, como se vê na tabela 3, quinta coluna. A fração dos títulos com correção cambial no total da dívida interna líquida é obtida usando-se a hipótese de que seja igual à sua participação no total dos títulos públicos federais fora do BCB.

\footnotetext{
${ }^{12}$ O parâmetro escolhido para a razão capital-produto é resultado parcial da pesquisa do Ipea/RJ, realizada por Lucilene Morandi, sobre estoque de riqueza no Brasil. Seu trabalho indica que o estoque líquido de capital relativo ao PIB corresponde a 2,99 em 2000.
} 
Tabela 3

Dívida líquida do setor público: Brasil

\begin{tabular}{|c|c|c|c|c|c|c|}
\hline \multirow[t]{2}{*}{ Data } & \multicolumn{2}{|c|}{$\begin{array}{l}\text { Dívida líquida interna } \\
(\% \text { PIB })\end{array}$} & \multicolumn{2}{|c|}{$\begin{array}{l}\text { Dívida líquida extern } \\
\text { (\% PIB) }\end{array}$} & \multirow{2}{*}{$\begin{array}{l}\text { a Dívida } \\
\text { líquida } \\
\text { total } \\
(\% \mathrm{PIB}) \\
\end{array}$} & \multirow{2}{*}{$\begin{array}{c}\text { Participação da } \\
\text { dívida interna } \\
\text { sem cambiais } \\
\text { na total } \\
\end{array}$} \\
\hline & total & $\begin{array}{l}\text { sem títulos } \\
\text { cambiais }\end{array}$ & total & $\begin{array}{l}\text { com títulos } \\
\text { cambiais }\end{array}$ & & \\
\hline Jun. 1999 & 38,7 & 29,4 & 10,5 & 19,8 & 49,2 & 60 \\
\hline Jul. 1999 & 38,9 & 29,4 & 10,5 & 20,0 & 49,4 & 60 \\
\hline Ago. 1999 & 39,1 & 28,9 & 11,1 & 21,3 & 50,2 & 58 \\
\hline Set. 1999 & 38,4 & 28,3 & 10,8 & 20,9 & 49,2 & 58 \\
\hline Out. 1999 & 38,1 & 27,9 & 10,8 & 21,0 & 48,9 & 57 \\
\hline Nov. 1999 & 37,2 & 27,5 & 10,6 & 20,3 & 47,8 & 58 \\
\hline Dez. 1999 & 39,0 & 29,6 & 10,4 & 19,8 & 49,4 & 60 \\
\hline Jan. 2000 & 37,5 & 28,7 & 9,7 & 18,5 & 47,2 & 61 \\
\hline Fev. 2000 & 37,9 & 29,2 & 9,5 & 18,2 & 47,4 & 62 \\
\hline Mar. 2000 & 37,8 & 29,3 & 9,3 & 17,8 & 47,1 & 62 \\
\hline Abr. 2000 & 37,7 & 29,7 & 9,8 & 17,8 & 47,5 & 63 \\
\hline Maio 2000 & 37,6 & 29,7 & 9,8 & 17,7 & 47,4 & 63 \\
\hline Jun. 2000 & 37,0 & 29,4 & 9,5 & 17,1 & 46,5 & 63 \\
\hline Jul. 2000 & 39,6 & 31,6 & 9,9 & 17,9 & 49,5 & 64 \\
\hline Ago. 2000 & 39,1 & 31,0 & 9,5 & 17,6 & 48,6 & 64 \\
\hline Set. 2000 & 39,0 & 31,0 & 9,5 & 17,5 & 48,5 & 64 \\
\hline Out. 2000 & 40,5 & 32,0 & 10,4 & 18,9 & 50,9 & 63 \\
\hline Nov. 2000 & 39,7 & 31,0 & 10,0 & 18,7 & 49,7 & 62 \\
\hline Dez. 2000 & 39,5 & 30,9 & 9,7 & 18,3 & 49,2 & 63 \\
\hline Jan. 2001 & 40,1 & 31,4 & 8,8 & 17,5 & 48,9 & 64 \\
\hline Fev. 2001 & 40,5 & 31,4 & 9,1 & 18,2 & 49,6 & 63 \\
\hline Mar. 2001 & 40,4 & 31,0 & 9,8 & 19,2 & 50,2 & 62 \\
\hline Abr. 2001 & 40,4 & 30,5 & 10,0 & 19,9 & 50,4 & 61 \\
\hline Maio 2001 & 41,0 & 30,1 & 10,9 & 21,8 & 51,9 & 58 \\
\hline
\end{tabular}

Fonte: Elaboração própria a partir de dados do BCB.

Para simular o modelo com duas dívidas e política monetária sob controle nacional, outros três parâmetros são necessários. Primeiramente, tem-se a parcela da dívida em moeda local efetivamente paga, $\vartheta$. Conforme especificado no modelo, este parâmetro é definido como inverso do fator de inflação. Considerando-se que a taxa de inflação é de 14\% entre junho de 1999 e maio de 2001, segundo o índice de preços ao consumidor amplo, do IBGE, resulta que o parâmetro $\vartheta$ toma o valor 0,88 na calibração. 
Suponha, como é o caso deste exercício numérico, que a dívida pública total equivale a $50 \%$ do PIB, sendo $20 \%$ correspondentes à dívida em dólar e o restante à dívida em moeda local. Se os banqueiros internacionais estão inclinados a não conceder novos empréstimos, então, com o intuito de evitar a suspensão dos pagamentos da dívida externa, o governo resolve fazer um ajuste fiscal de cerca de $5 \%$ do PIB e também pagar apenas uma fração $\vartheta$ da dívida em moeda local. Sabemos que um título da dívida interna paga, no período seguinte, uma unidade do bem ao preço da data anterior, em moeda local. Para o governo dispor de $15 \%$ do PIB de receitas extras para pagar a dívida externa, qual inflação deve realizar?

Se o governo paga metade do valor real da dívida, então os credores têm seu poder de compra reduzido à metade, ou seja, é como se os preços tivessem subido $100 \%$. Mais especificamente, suponha que inicialmente o preço nominal de cada título da dívida em moeda local seja $\beta \cdot \mathrm{R} \$ 1$ e que o preço de uma unidade do bem seja $\mathrm{R} \$ 1$. A despesa de um credor nacional, em termos nominais, é de $10 \cdot \beta \cdot \mathrm{R} \$ 1$ na aquisição de 10 títulos. No período seguinte, esta aplicação dá ao credor $\mathrm{R} \$ 10$, e, caso não houvesse inflação, ele/ela poderia comprar 10 unidades do bem. No entanto, se a inflação for de 100\%, o resultado da aplicação mantém-se em $\mathrm{R} \$ 10$, porém o credor só adquirirá cinco unidades do bem, e não 10. O governo fica com as outras cinco unidades, que são utilizadas para pagar a dívida externa. Logo, a receita do governo proveniente da inflação, em unidades do bem, corresponde a $\left(1-p_{-1} / p\right) * D$, onde $D$, é a quantidade de títulos da dívida interna. Para o Brasil, dado que $\vartheta$ é parametrizado em 0,88 , então esta expressão equivale a $(1-0,88) \cdot 0,30$, que significa que o imposto inflacionário é equivalente a $3,6 \%$ do PIB no período de junho de 1999 a maio de 2001. No entanto, se o governo brasileiro desejasse pagar os restantes $15 \%$ do PIB, referentes à dívida em dólar, então deveria abater a dívida em moeda local em 50\%, ou seja $\vartheta=0,5$. Neste caso, a inflação corresponderia a 100\%.

Outro parâmetro do modelo Cole-Kehoe com duas dívidas é a probabilidade $\xi$ de a dívida em moeda local ser paga parcialmente. Em alguns exercícios, supõe-se $\xi$ como a fração da dívida em moeda local no total da dívida pública. Esta hipótese indica, grosso modo, uma maior atratividade, dos títulos em moeda local em relação aos títulos em dólar para os credores domésticos, que gera expectativa de desvalorização cambial. A dívida em moeda local corresponde à dívida líquida interna, exclusive os títulos federais 
com correção cambial. De acordo com a tabela 3, a participação percentual da dívida interna líquida sem cambiais na dívida interna líquida total do setor público corresponde à média de $60 \%$ no período de análise. ${ }^{13}$

$\mathrm{O}$ último parâmetro corresponde à constante $\psi$, que indica o peso que o setor privado atribui ao banco central ser independente. Consideram-se $\psi=0$, que é o caso do banco central independente, e $\psi=1 / \xi$, o caso extremo de sofrer fortes pressões políticas com certeza.

\subsection{Análise dos resultados}

O primeiro exercício consiste em estimar a zona de crise para o Brasil, supondo que toda a sua dívida esteja denominada em dólar e empregando o mesmo procedimento de Cole-Kehoe (1996), com os parâmetros calibrados acima.

A figura 1 mostra a zona de crise, para distintas maturidades médias dos títulos da dívida, que está representada por duas curvas. O limite superior constitui a curva denominada de restrição de participação estacionária e o limite inferior forma a curva chamada de condição de não-empréstimos, que correspondem a, respectivamente, $\bar{B}\left(k^{n}\right)$ e $\bar{b}\left(k^{n}\right)$ para diferentes maturidades médias da dívida.

O principal resultado desta simulação é a dívida do setor público total, correspondente à fração de 0,50 , relativa ao PIB e com maturidade média de dois anos, estar na zona de crise. Este ponto está indicado pelo símbolo * na figura 1. Cole e Kehoe sugerem duas políticas que o governo deve adotar para sair da zona de crise: diminuir periodicamente o nível da dívida e aumentar sua maturidade. ${ }^{14}$ De acordo com a simulação, se a maturidade média fosse

\footnotetext{
${ }^{13}$ Atualmente, está em elaboração um procedimento para o cálculo de $\xi$, análogo ao da probabilidade $\pi$, através da seguinte expressão:

$$
\xi=1-\left(\frac{1+r}{1+i}\right)^{\frac{1}{n}}
$$

onde $r$ é a taxa de juros anualizada, até a maturidade dos títulos da dívida pública brasileira em dólar e $i$ é a taxa de juros, anualizada, até a maturidade dos títulos da dívida pública brasileira em real. O spread entre estes dois títulos é uma definição para o risco de desvalorização, empregada em trabalhos empíricos, por exemplo, no de Ahumada e Garegnani (2001).

${ }^{14}$ Em um artigo recente, Phelan (2000) não concorda com as propostas de diminuir a emissão de divida de curto prazo. Ele desenvolve um modelo teórico, com as seguintes diferenças principais, relativamente ao de Cole-Kehoe: as preferências dos consumidores e do governo, por serviços públicos, são afetadas por um choque comum e o governo não é suposto benevolente. Usando estas hipóteses e considerando uma economia semelhante à de Lucas e Stokey (1983), o autor obtém, como resultado de um jogo, um conjunto de equilíbrio idêntico, tanto com dívida de vários períodos, quanto com dívida de um período. Assim, ele mostra que a estrutura a termo da dívida é irrelevante para se atingir o equilíbrio.
} 
de três anos, a razão dívida-PIB estaria sobre a curva debaixo da zona de crise e livre de incertezas. Além disso, mantendo-se a maturidade média em dois anos, é preciso reduzir a dívida, no mínimo, até a fração de 0,36 do PIB e, assim, sair da zona de crise.

Figura 1

Zona de crise - Brasil - 1999-2001

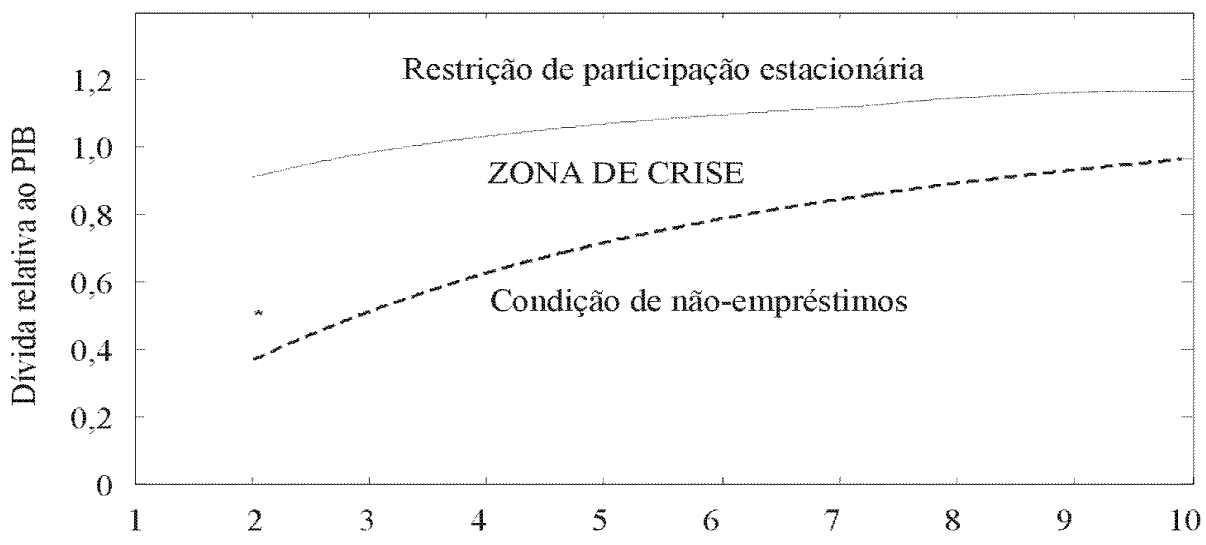

Maturidade média da divida do governo em anos

A seguir, comparam-se os níveis de bem-estar do modelo Cole-Kehoe original com o de duas dívidas. Em todas as simulações, adotam-se as seguintes hipóteses: a maturidade média dos títulos da dívida em dólar e em moeda local é de dois anos; a dívida em moeda local é constante e igual a 0,30 relativamente ao PIB, enquanto a dívida em dólar, $B$, varia; e o governo segue uma política de endividamento em dólar estacionário, ou seja, dado um nível de dívida em dólar inicial, ele sempre escolhe esta mesma dívida.

A comparação entre os modelos Cole-Kehoe original, que não inclui moeda local, e o com duas moedas é feita primeiramente supondo-se que não há incerteza a respeito de o governo cumprir o pagamento de sua dívida em dólar no período seguinte. Este resultado é apresentado na figura 2, que mostra o bem-estar do governo variando com a razão dívida total relativa ao PIB.

O bem-estar para o modelo Cole-Kehoe original é identificado pela curva tracejada. Na ausência de incerteza, o governo sem moeda local obtém empréstimos em dólar até a fração máxima de $\bar{B}\left(k^{n}\right) / \mathrm{PIB}$, igual a 0,92. Para dívidas mais elevadas, não há empréstimos e o bem-estar corresponde ao de uma moratória do governo. Além disso, o bem-estar do governo declina com 
o endividamento, refletindo a crescente despesa com o pagamento de juros sobre um estoque que está aumentando. Já o bem-estar para o modelo de duas dívidas é indicado pela curva cheia e verifica-se que ela está deslocada para a direita, relativamente à curva do modelo Cole-Kehoe original. Para uma determinada razão dívida total-PIB, no intervalo entre $D /$ PIB igual a 0,30 e $\bar{B}\left(k^{n}\right) / \mathrm{PIB}$ de 0,92 , o bem-estar do governo com moeda local é cerca de $5 \%$ maior do que o do modelo com uma moeda. No entanto, para dívida total abaixo da fração 0,15 , o bem-estar do modelo sem moeda local é maior.

Figura 2

Modelos sem incerteza - Brasil

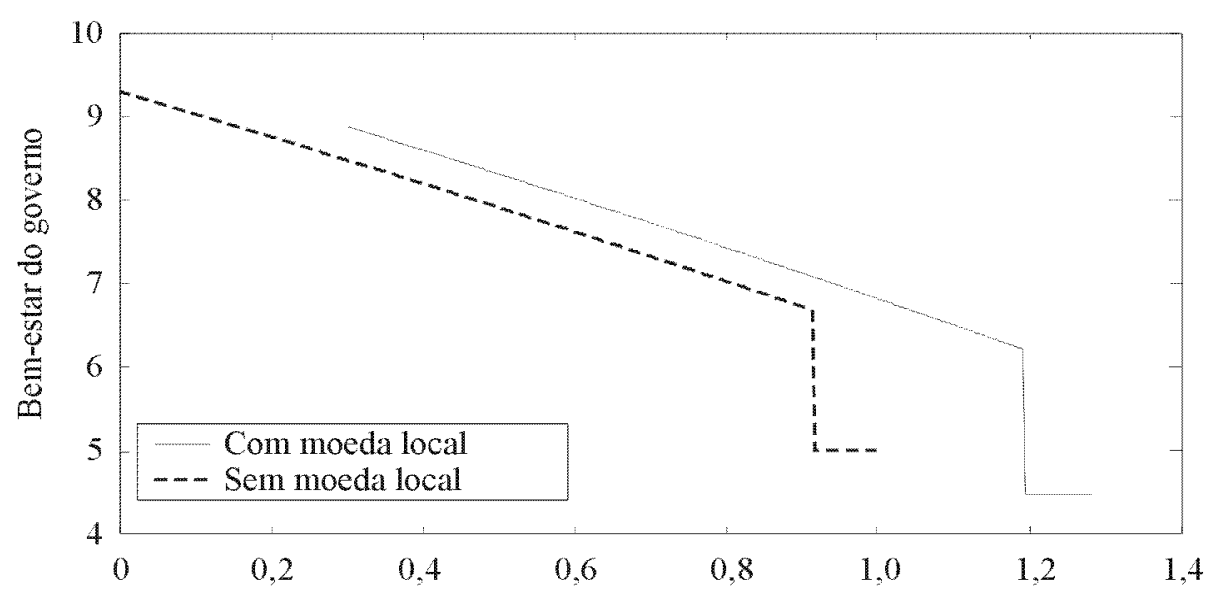

Dívida total relativa ao PIB

Conforme suposto no modelo de duas dívidas, a dívida em moeda local está fixa na razão de 0,30 relativa ao PIB e, portanto, a curva de bem-estar do governo com moeda local começa deste nível de endividamento. A dívida em dólar corresponde à diferença entre a dívida total e a dívida em moeda local. Sendo o nível mais elevado da dívida total do governo igual à fração de 1,19 do PIB, então os credores externos emprestam, no máximo, $\bar{B}\left(k^{n}, D\right) / \mathrm{PIB}$ equivalente a 0,89. Este nível mais elevado da dívida em dólar que os banqueiros internacionais estão dispostos a emprestar na ausência de incerteza é ligeiramente menor do que o do modelo Cole-Kehoe original. Esta diferença é resultado de as despesas com o pagamento de juros sobre a dívida em moeda local reduzirem os recursos disponíveis para que o governo pague a dívida externa. 
A figura 3 é semelhante à figura 2, com a inclusão de incerteza e também o bem-estar de um governo com banco central sujeito a fortes pressões políticas. $\mathrm{Na}$ curva de bem-estar do governo sem moeda local, até o limite inferior da zona de crise de probabilidade $\pi, \bar{b}\left(k^{n}\right) / \mathrm{PIB}$, os credores externos sabem que o governo prefere pagar a sua dívida externa do que repudiá-la, mesmo na ausência de empréstimos. Na figura 3, este patamar da dívida é igual a 0,36 e corresponde exatamente à dívida relativa ao PIB, que o bem-estar do governo sem moeda local (a curva tracejada) salta de 8,3 para 6,1. Logo, até este patamar da razão dívida-PIB, a curva de bem-estar do governo sem moeda local é igual à da figura 2. Acima de $\bar{b}\left(k^{n}\right) / \mathrm{PIB}$ há incerteza. Os banqueiros internacionais atribuem probabilidade positiva $\pi$ de que o governo faça moratória da dívida em dólar no período seguinte. Além disso, a dívida em dólar é mantida estacionária, por hipótese. Dada a presença de incerteza, o governo vende sua dívida em dólar a um preço mais baixo e os consumidores acumulam menos capital em todos os períodos. Desse modo, o bem-estar do governo é menor do que na ausência de dúvida sobre o cumprimento de suas obrigações, como é o caso da figura 2.

Do mesmo modo, a curva de bem-estar do governo com moeda local e banco central puro é igual à da figura 2 até a dívida total no PIB igual 0,65. Neste patamar da dívida, a curva de bem-estar do governo com moeda local cai de 7,9 para 6,3, porque as dívidas em dólar mais elevadas geram desconfiança nos credores externos a respeito do governo. No modelo ColeKehoe com duas moedas, para dada dívida em moeda local $D$, os banqueiros internacionais renovam os empréstimos com certeza até o limite da dívida em dólar $\bar{b}\left(k^{n}, D\right) /$ PIB equivalente a 0,35 .

Na figura 3, há duas curvas para representar o modelo Cole-Kehoe com moeda local: uma, cheia, que representa a curva de bem-estar do governo, quando o banco central está completamente isento de pressões políticas (BC puro e $\psi \xi=0)$; e a outra, com ponto e traço, representa o bem-estar do governo, com banco central sujeito a pressões políticas para inflacionar a moeda local, na ausência de crise externa (BC ruim e $\psi \xi=1)$. Estas duas curvas estão muito próximas até a razão dívida total no PIB igual a 0,65, que corresponde à soma da dívida em moeda local com o nível mais alto da dívida em dólar, para o qual o governo prefere não fazer moratória desta dívida, mesmo na ausência de empréstimos externos, dado por $\bar{b}\left(k^{n}, D\right) / \mathrm{PIB}$. Comparandose estas duas curvas, verifica-se que, até este patamar da dívida, o bem-estar 
do governo com banco central ruim está acima do bem-estar do governo com banco central puro - cerca de $1 \%$. A justificativa para este resultado é a que se segue.

Figura 3

Modelos com incerteza - Brasil

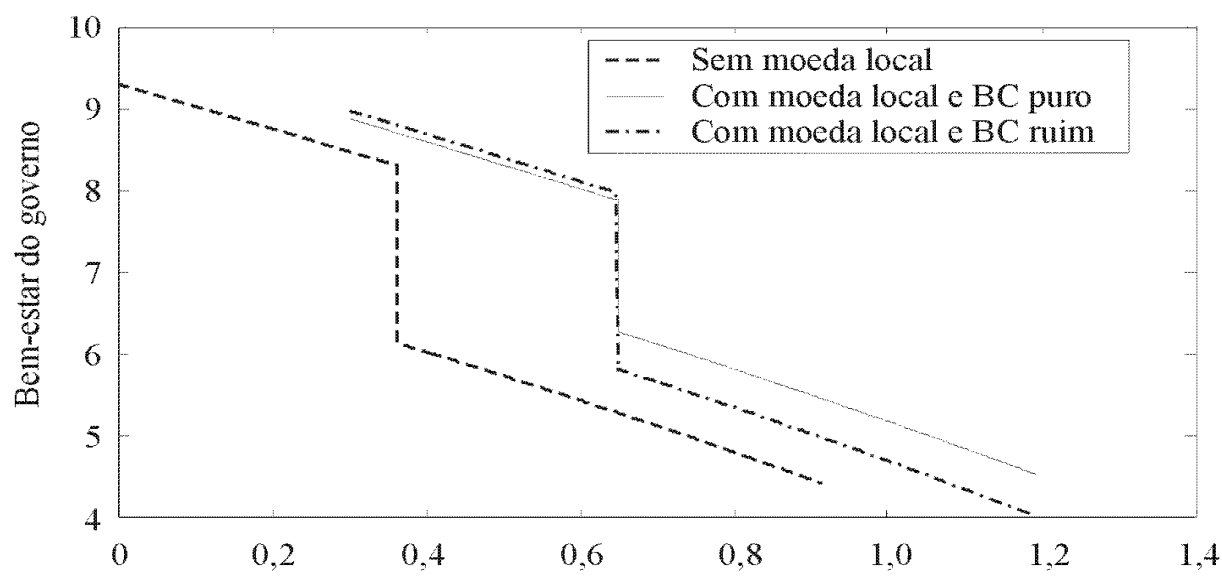

Dívida total relativa ao $\mathrm{PIB}$

Na data em que o banco central ruim realiza a inflação-surpresa, a queda da utilidade do consumidor relativa ao menor consumo privado, correspondente a $(\phi-1) D$, é menor do que o efeito do aumento da utilidade gerada pelo aumento dos gastos públicos de $(1-\phi) D$. Do mesmo modo, nos períodos posteriores, a queda do consumo é de $(\phi-1)(1-\beta) D$ e o aumento dos gastos públicos, desta mesma quantidade de bens, provoca um benefício ainda maior do que a perda de utilidade do consumo privado. Este resultado é fruto da escolha dos parâmetros e da especificação da função utilidade dos gastos do governo, $v$. O efeito dos gastos públicos é avaliado na parte negativa da função logarítimica. Assim, pequenas diferenças nos gastos públicos geram variações maiores do que na porção positiva desta função. Portanto, nesta simulação na ausência de incerteza, a inflação surpresa pode gerar um bem-estar ligeiramente maior do que no caso de um banco central que nunca procede desta forma.

Por outro lado, quando há incerteza a respeito do compromisso do governo de cumprir com os pagamentos da sua dívida, o bem-estar do governo com banco central independente é sempre maior do que com banco central ruim. Esta diferença corresponde a cerca de $8 \%$ a $12 \%$ do bem-estar do governo com 
banco central ruim. Para dívida em dólar acima de $\bar{b}\left(k^{n}, D\right)$, há probabilidade positiva de haver crise. Se o governo utiliza o recurso da inflação, sem que haja crise da dívida externa (como é o caso do BC ruim), então, a partir deste período, ele não tem mais esta alternativa à sua disposição e a probabilidade de crise sobre a sua dívida em dólar é $\pi$. No entanto, se não tivesse optado por inflacionar a moeda local, a probabilidade de crise da dívida em dólar seria de $\pi(1-\xi)$, isto é, menor do que $\pi$. Uma desconfiança menor dos credores externos implica maior bem-estar para o governo, porque, assim, eles conseguem vender seus títulos a preço mais alto e os consumidores estão dispostos a acumular mais capital.

O salto que as curvas de bem-estar da figura 3 realizam, quando a dívida em dólar passa para um patamar que gera desconfiança nos credores externos, é de cerca de $25 \%$ para o bem-estar do governo com moeda local e banco central puro, de $37 \%$ para o bem-estar do governo com banco central ruim e de $36 \%$ para o bem-estar do governo sem moeda local. De acordo com o modelo original de Cole-Kehoe, este salto é muito maior do que o que ocorreria caso o governo não seguisse uma política de endividamento estacionário. Na figura 4 supõe-se que o governo sem moeda local não esteja seguindo uma política de endividamento estacionário e, ao contrário, esteja escolhendo otimamente sua dívida em dólar para o próximo período, na presença de incerteza. É isto que Cole e Kehoe (1996) fazem na sua simulação para o México. Eles observam que, com incerteza e um nível de endividamento inicial na zona de crise, a escolha ótima da dívida não é a mesma da inicial e, em geral, é menor. Assim, o salto do bem-estar, quando é suposto que o governo siga uma política de endividamento estacionário na zona de crise, reflete uma escolha da dívida acima do desejado e com um preço inferior ao da ausência de incerteza. Desse modo, a queda do bem-estar do governo, no modelo sem moeda local, atinge cerca de $36 \%$, quando a dívida atinge um patamar que gera desconfiança nos credores externos. No entanto, quando o governo escolhe otimamente a sua dívida, esta queda é de apenas $2,5 \%$.

A comparação das figuras 3 e 4 tem como objetivo mostrar o efeito que a hipótese de política de endividamento estacionário na zona de crise produz. Primeiro, o bem-estar do governo é menor do que quando escolhe otimamente sua dívida e, segundo, o nível mais alto da dívida para o qual os credores emprestam, $B\left(k^{\pi}, \pi\right)$ é menor, também. Com política de endividamento estacionário, é suposto que este limite superior seja dado por $B\left(k^{n}\right) / P I B$ igual 
a 0,92; porém, com a escolha da dívida, o limite superior da dívida em dólar para o qual os credores externos estão dispostos a emprestar, dada a probabilidade $\pi$ de uma crise da dívida externa ocorrer no período seguinte, é $B\left(k^{\pi}, \pi\right) / \mathrm{PIB}$, igual a 0,75 . Portanto, uma das conclusões deste artigo é que novos esforços sejam direcionados para se incluir a decisão do governo a respeito da sua dívida, no exercício numérico do modelo Cole-Kehoe com moeda local.

Figura 4

Modelos com incerteza - Brasil

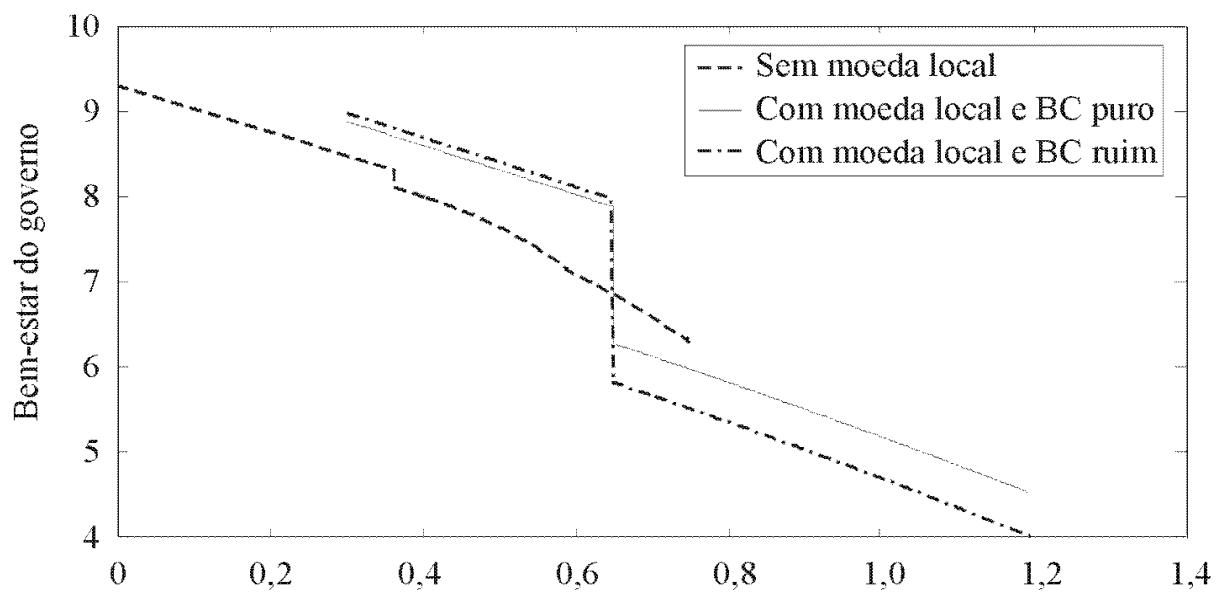

Divida total relativa ao PIB

O mesmo tipo de efeito da figura 3 é observado na figura 5, na qual se supõe que a dívida em dólar, $B$, e a dívida em moeda local, $D$, estejam fixas em $20 \%$ e $30 \%$ do PIB, respectivamente. Nesta figura, analisa-se o comportamento do bem-estar do governo, no modelo de duas dívidas, à medida que a probabilidade de o governo fazer moratória parcial da dívida em moeda local, $\xi$ (CSI), varia. Analisam-se três curvas de bem-estar, de acordo com a hipótese feita para o tipo de banco central: puro, $\psi=0$, correspondente à curva cheia; ruim, com $\psi=0,5$, a curva com tracejado e ponto; e ruim, com $\psi=1 / \xi$, a curva só com tracejado. Verifica-se que, para $\xi$ baixo e inferior a 0,11 , o bem-estar do governo com banco central ruim é maior do que o bem-estar do governo com banco central puro. A justificativa para este resultado é muito semelhante à utilizada para o da figura 3. Quanto menor $\xi$, maior a utilidade do consumidor, no instante da decisão do governo de fazer inflação-surpresa, porque o efeito do aumento dos gastos públicos mais do que 
compensa a queda do consumo do bem privado. Nos instantes posteriores, o governo do banco central ruim, $\operatorname{com} \psi=1 / \xi$, enfrenta probabilidade de crise $\pi$ e seu bem-estar esperado não depende mais de $\xi$. Já o governo do banco central puro enfrenta probabilidade de crise $\pi$, que varia inversamente com $\xi$. Logo, quanto maior $\xi$, menor a incerteza para os credores externos e mais elevado o bem-estar esperado do governo. Por fim, quando $\psi$ não for os casos extremos, então o bem-estar é um resultado intermediário aos outros dois.

\section{Figura 5}

Modelo duas dividas - B, D fixos

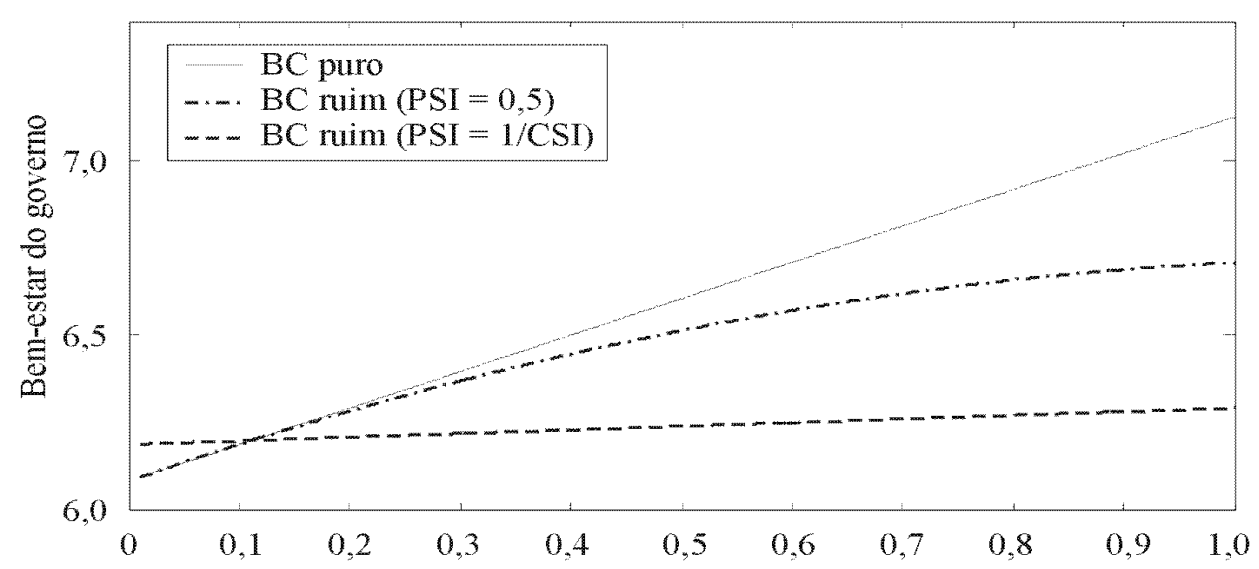

Probabilidade de moratória parcial da dívida em moeda local (CSI)

\section{Conclusão}

A extensão do modelo Cole-Kehoe com duas moedas traz uma perspectiva nova para a discussão da dolarização: o modelo original sendo análogo ao de uma economia dolarizada e o com duas moedas reproduzindo uma economia que emite moeda. A comparação entre estas duas situações é feita pela avaliação dos níveis de bem-estar de um governo benevolente para diferentes níveis da dívida do setor público. Uma hipótese forte é usada nestas simulações. Supõe-se que o governo siga uma política de endividamento estacionário e não escolha seu novo nível de endividamento. Quando manchas solares são levadas em consideração, este comportamento não é aquele que maximiza o bem-estar do governo para todos os níveis iniciais da dívida. Portanto, as simulações feitas aqui devem ser analisadas com cuidado. Os resultados não permitem que se afirme que o modelo com duas moedas produza níveis de bem-estar 
mais elevados do que o modelo com apenas uma. O relaxamento daquela hipótese pode produzir resultados completamente distintos dos encontrados e este é um tópico importante para pesquisa futura.

\section{Referências Bibliográficas}

Ahumada, Hildegart A. \& Garegnani, Maria Lorena. Econometric modelling of Argentine default and devaluation risks. In: Latin American Meeting of the Econometric Society, 28. Buenos Aires, 2001. http://www. udesa.edu.ar/lames2001/papers/garegnani.doc.

Araujo, Aloisio \& Leon, Marcia. Ataques especulativos sobre dívidas e dolarização. Rio de Janeiro, EPGE/FGV, 2001. mimeog.

Cole, Harold L. \& Kehoe, Timothy J. A self-fulfilling model of Mexico's 19941995 debt crisis. Journal of International Economics. Amsterdam, NorthHolland. 41:309-30, 1996.

. Self-fulfilling debt crises. Minneapolis, Federal Reserve Bank, Research Department, 1998. (Staff Report, 211.)

. Self-fulfilling debt crises. Review of Economic Studies. London, Blackwell, 6r(1):91-116, Jan. 2000.

Ellery Jr., Roberto; Gomes, Victor \& Sachsida, Adolfo. Business cycle fluctuations in Brazil. In: Encontro Brasileiro de Econometria, 22. Anais. Rio de Janeiro, Sociedade Brasileira de Econometria, 2000.

Lucas, Robert E. \& Stokey, Nancy L. Optimal fiscal and monetary policy in an economy without capital. Journal of Monetary Economics, 12(1):55-93, 1983.

Phelan, Christopher. On the irrelevance of the maturity structure of government debt without commitment. Minneapolis, Federal Reserve Bank of Minneapolis, 2000. (Staff Report, 268.)

Receita Federal. Tributação na fonte e sobre operações financeiras. Livro 3, art. 620 a 786. In: http://www.receita.fazenda.gov.br/Legislacao/RIR/ Livro3.htm. 24-8-2001.

Sargent, Thomas J. Comment on "Fiscal consequences for Mexico of adopting the dollar". In: http://www.stanford.edu/ sargent. June 2000. 
Sims, Christopher A. Fiscal consequences for Mexico of adopting the dollar. In: Optimal Monetary Institutions for Mexico. Anais. Mexico D.F., Instituto Tecnológico Autónomo de México, dez. 1999. http://www. princeton.edu/ sims/\#Papers.

\section{Anexo}

O nível de bem-estar $V^{\pi \xi}$ corresponde a:

$$
\begin{aligned}
& V^{\pi \xi}(s, B, \beta(1-\pi+\pi \xi), D, \beta[1-\pi+\pi(1-\xi)+\phi \pi \xi])= \\
& \quad=\frac{1}{1-\beta(1-\pi)} u^{n}\left(k^{\pi \xi}\right)+\frac{\beta \pi(1-\xi)}{1-\beta(1-\pi)}\left[u^{d}\left(k^{\pi \xi}\right)+\beta w_{d D}\right]+ \\
& \quad+\frac{\beta \pi \xi}{1-\beta(1-\pi)}\left[u^{d p}\left(k^{\pi \xi}\right)+\beta V^{\pi}\left(\left(k^{\pi}, B, D, 1, \phi, \zeta, \cdot\right), B, \beta(1-\pi), D, \beta \phi\right)\right] \\
& \quad u^{n}\left(k^{\pi \xi}\right)=\varrho\left\{(1-\theta) y^{\pi \xi}+(1-\beta[1-\pi+\pi(1-\xi)+\phi \pi \xi]) D\right\}+ \\
& \quad+v\left\{\theta y^{\pi \xi}-[1-\beta(1-\pi+\pi \xi)] B-(1-\beta[1-\pi+\pi(1-\xi)+\phi \pi \xi]) D\right\} \\
& u^{d}\left(k^{\pi \xi}\right)=\varrho\left\{(1-\theta)\left[\alpha f\left(k^{\pi \xi}\right)-\delta k^{\pi \xi}\right]-k^{d}+k^{\pi \xi}+(1-\beta) D\right\}+ \\
& \quad+v\left[\theta\left(\alpha f\left(k^{\pi \xi}\right)-\delta k^{\pi \xi}\right)-(1-\beta) D\right] \\
& w_{d D}=\frac{1}{1-\beta}\left\{\varrho\left\{(1-\theta)\left[\alpha f\left(k^{d}\right)-\delta k^{d}\right]+(1-\beta) D\right\}+\right. \\
& \left.\quad+v\left[\theta\left(\alpha f\left(k^{d}\right)-\delta k^{d}\right)-(1-\beta) D\right]\right\}
\end{aligned}
$$$$
\begin{gathered}
u^{d p}\left(k^{\pi \xi}\right)=\varrho\left\{(1-\theta) y^{\pi \xi}-k^{\pi}+k^{\pi \xi}+\phi(1-\beta) D\right\}+ \\
+v\left[\theta y^{\pi \xi}-(1-\beta(1-\pi)) B-\phi(1-\beta) D\right]
\end{gathered}
$$$$
V^{\pi}\left(\left(k^{\pi}, B, D, 1, \phi, \zeta, \cdot\right), B, \beta(1-\pi), D, \beta \phi\right)=\frac{(1-\pi)}{1-\beta(1-\pi)} u^{\pi}\left(k^{\pi}, \phi\right)+
$$$$
+\frac{\pi}{1-\beta(1-\pi)} u^{d}\left(k^{\pi}, \phi\right)+\frac{\beta \pi}{(1-\beta)[1-\beta(1-\pi)]} u^{d}\left(k^{d}, \phi\right)
$$

$$
\begin{aligned}
& u^{\pi}\left(k^{\pi}, \phi\right)=\varrho\left\{(1-\theta)\left[f\left(k^{\pi}\right)-\delta k^{\pi}\right]+\phi(1-\beta) D\right\}+ \\
& \quad+v\left\{\theta\left[f\left(k^{\pi}\right)-\delta k^{\pi}\right]-\phi(1-\beta) D-[1-\beta(1-\pi)] B\right\}
\end{aligned}
$$




$$
\begin{aligned}
& u^{d}\left(k^{\pi}, \phi\right)=\varrho\left\{(1-\theta)\left[\alpha f\left(k^{\pi}\right)-\delta k^{\pi}\right]-k^{d}+k^{\pi}+\phi(1-\beta) D\right\}+ \\
& +v\left\{\theta\left[\alpha f\left(k^{\pi}\right)-\delta k^{\pi}\right]-\phi(1-\beta) D\right\} \\
& u^{d}\left(k^{d}, \phi\right)=\varrho\left\{(1-\theta)\left[\alpha f\left(k^{d}\right)-\delta k^{d}\right]+\phi(1-\beta) D\right\}+ \\
& \quad+v\left\{\theta\left[\alpha f\left(k^{d}\right)-\delta k^{d}\right]-\phi(1-\beta) D\right\}
\end{aligned}
$$

